1 This manuscript is a preprint and has been accepted for publication in Journal of

2 Volcanology and Geothermal Research. Please feel free to contact me with any comments 3 or feedback on our study.

4

6

Please cite this work as:

Haag, M.B., Sommer, C.A., Savian, J.F., Caselli, A.T., Moncinhatto, T.R., Hartmann, G.A., Ort, M.H., Poletti, W., da Trindade, R.I.F., 2021. AMS and rock magnetism in the CaviahueCopahue Volcanic Complex (Southern Andes): Emission center, flow dynamics, and implications to the emplacement of non-welded PDCs. Journal of Volcanology and Geothermal Research 107283. https://doi.org/10.1016/j.jvolgeores.2021.107283 


\section{AMS and rock magnetism in the Caviahue-Copahue Volcanic Complex (Southern Andes): emission center, flow dynamics, and implications to the emplacement of non-welded PDCs}

Mauricio Barcelos Haag ${ }^{a,}$, , Carlos Augusto Sommer ${ }^{a}$, Jairo Fransciso Savian ${ }^{a}$, Alberto Tomás Caselli ${ }^{b}$, Thiago Ribas Moncinhatto ${ }^{c}$, Gelvam André Hartmann ${ }^{d}$, Michael H Orte, Wilbor Polettit, Ricardo Ivan Ferreira da Trindade ${ }^{c}$

${ }^{a}$ Instituto de Geociências, Universidade Federal do Rio Grande do Sul, Av. Bento Gonçalves 9500, 91501-970 Porto Alegre, RS, Brazil

${ }^{b}$ Laboratorio de Estudio y Seguimiento de Volcanes Activos, Universidad Nacional de Río Negro, Roca 1242, 8332 G. Roca, Rio Negro, Argentina

${ }^{c}$ Instituto de Astronomia, Geofísica e Ciências Atmosféricas, Universidade de São Paulo, Rua do Matão 1226, 05508-090 São Paulo, SP, Brazil

${ }^{d}$ Instituto de Geociências, Universidade Estadual de Campinas, Rua Carlos Gomes 250, 13083-855 Campinas, SP, Brazil

e School of Earth and Sustainability, Box 4099, Northern Arizona University, Flagstaff, AZ, 86011 USA

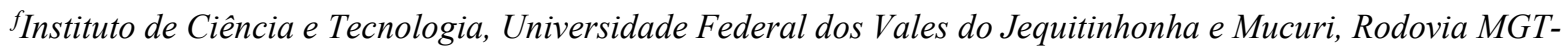
367, 5000, 39100-000 Diamantina, MG, Brazil

* Corresponding author: M.B. Haag

E-mail address: mauricio.haag@ufrgs.br / mauricio.barceloshaag@gmail.com

Twitter account: @haag_mauricio

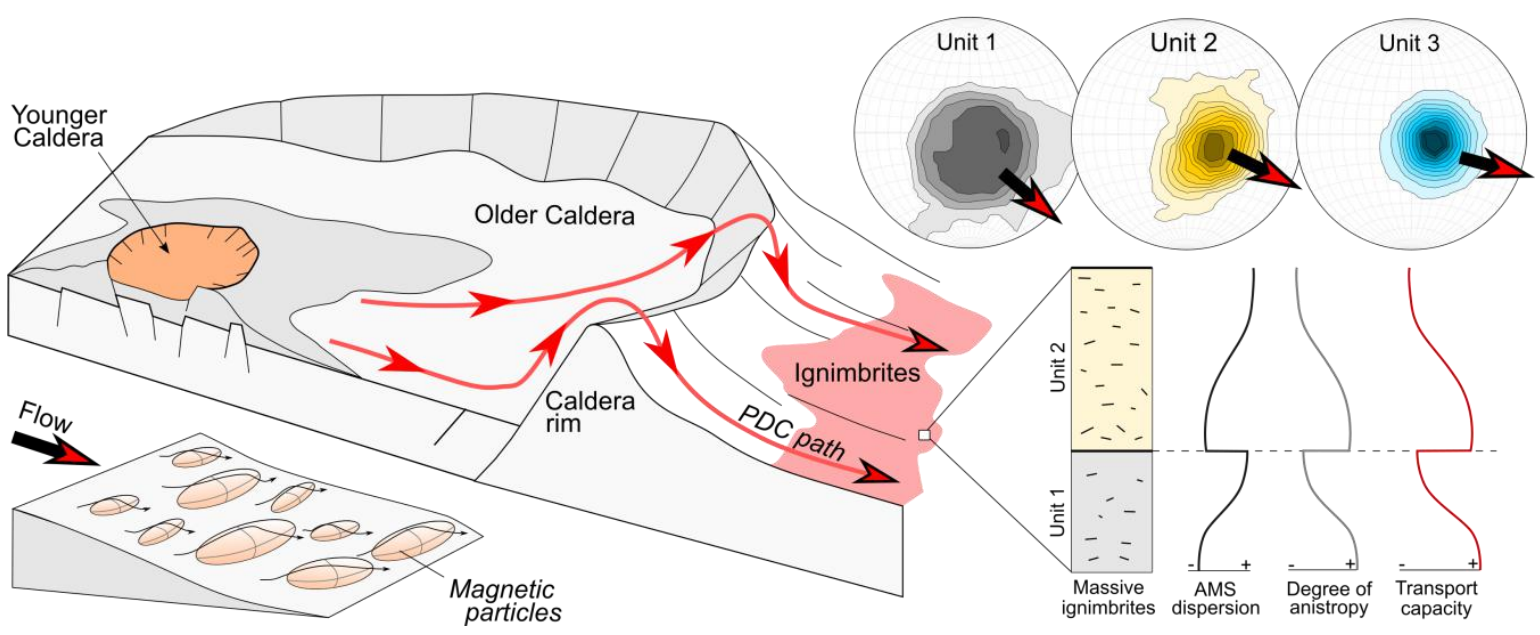




\section{Abstract}

Pyroclastic deposits can cover significant areas and register major geological events. Despite their importance, understanding depositional dynamics of pyroclastic density currents (PDCs) and linking explosive deposits to their emission centers is still a challenge, especially in the case of non-welded, massive ignimbrites. Located in the Southern Andes, the Caviahue Copahue Volcanic Complex (CCVC) comprises one of the most active volcanic centers in the Andean Belt. This volcanic complex hosts massive ignimbrites with both source emplacement poorly constrained, currently grouped in the Riscos Bayos Ignimbrites (RBI). In this contribution, we perform a full magnetic characterization and anisotropy of magnetic susceptibility (AMS) study on the massive RBI of the CCVC. The magnetic characterization was performed using magnetic experiments including isothermal remanet magnetization, thermomagnetic curves, hysteresis loops, first-order reversal curves, and scanning electron microscopy. Magnetic experiments indicate primary, multi-domain, high Curie temperature titanomagnetites as the AMS carriers. Ellipsoids are predominately oblate, with a low degree of anisotropy and east-southeastward imbrication. This fabric arrangement is consistent with PDC sedimentary fabrics deposited under laminar flow conditions. Despite RBI massive structure AMS data reveals changes in transport capacity of the PDC and particle organization. These changes are marked by increasing AMS dispersion and decreasing degree of anisotropy up-section within flow units. Directional statistics of AMS data implies the Las Mellizas Caldera as the emission center of RBI. The reconstructed flow path also suggests the PDC overrun of the Caviahue Caldera topographic rim. This study highlights the application of AMS to the identification of emission centers of explosive deposits, featuring its application to massive ignimbrites.

Keywords: Magnetic fabrics; Magnetic mineralogy; AMS; Pyroclastic density current; Nonwelded ignimbrite; Andes 


\section{Introduction}

Pyroclastic density currents (PDCs) are the main products of explosive volcanism and produce a wide variety of deposits, including welded to non-welded ignimbrites (Sparks, 1976;

Cas and Wright, 1987). These explosive deposits can cover extensive areas and record a significant portion of the geological history, as documented in the Snake River and Yellowstone Volcanic Province (USA; Morgan et al., 1984), Sierra Madre Occidental (Mexico; Ferrari et al., 2002), and the Altiplano-Puna Volcanic Complex (Argentina and Chile; de Silva, 1989; Lesti et al., 2011). Despite their geological significance, linking explosive deposits to their source areas and understanding depositional processes in PDCs is still a challenge, with several unresolved emission centers around the world (e.g., Morgan et al., 1984; Giordano et al., 2008; Agrò et al., 2014) and in the Andean Belt (e.g., Lesti et al., 2011; Ort et al., 2014; Platzmann et al., 2020). This happens because, in active regions tectonics and climate can rapidly modify volcanic landscapes, preferentially removing nonwelded deposits. As a consequence, the study of PDC deposits in these environments demands the application of alternative techniques. The anisotropy of magnetic susceptibility (AMS) is helpful to understand the mechanisms and flow dynamics of pyroclastic flow deposits.

AMS estimates the orientation of the magnetic particles of a given rock sample, detecting a rock fabric that can be used to study paleocurrent, deformation, and rheological processes in all kinds of rocks (Graham, 1954; Hrouda, 1982; Cañón-Tapia and MendozaBorunda, 2014). AMS studies have been applied to volcanic rocks, allowing the determination of source area, transport, and emplacement conditions of PDCs (e.g., Palmer and MacDonald, 1999; Ort et al., 2003; LaBerge et al., 2009; Cas et al., 2011; Cañón-Tapia and Mendoza-Borunda, 2014; Ort et al., 2014), lavas (e.g., Cañón-Tapia et al., 1997; Benites et al., 2020; Pasqualon et al., 2020, Haag et al., 2021) and dikes and sills (e.g., Magee et al., 
2012). Nevertheless, how PDC processes are recorded in magnetic fabrics is still debated because many factors can influence the petrofabrics to produce a variety of AMS fabrics (e.g., Ort et al., 2014; Cañón-Tapia and Mendoza-Borunda, 2014). The presence of extensive ignimbrite deposits in the Caviahue-Copahue Volcanic Complex (CCVC) in northern Patagonia provides a key area for the study of AMS fabrics in ignimbrites. Located in the southern Andes (between Argentina and Chile), the CCVC (Fig. 1) comprises one of the most active volcanic centers in this orogenic segment (Caselli et al., 2016; Tassi et al., 2016). Despite the young age (<5 Ma, Linares et al., 1999), CCVC deposits were strongly affected by Pleistocene glaciations (Díaz, 2003; Varekamp et al., 2006; Báez et al., 2020a), leading to a fragmented record and establishing a geologic puzzle, especially in the case of the more friable, volcaniclastic deposits. As a result, the explosive deposits in the CCVC provide an excellent case for the study of AMS fabrics in non-welded ignimbrites. The Riscos Bayos Ignimbrites (RBI), located a few kilometers outside the southern border of the Caviahue Caldera (Melnick et al., 2006), consist of a sequence of predominantly non-welded ignimbrites with restricted outcrops (Mazzoni and Licitra, 2000; Varekamp et al., 2006). This unique low-grade ignimbrite sequence (RBI) in the region is a significant geologic unit for the understanding of the CCVC (Mazzoni and Licitra, 2000), as well as a case study for the determination of emission centers of large-volume, non-welded PDCs deposits.

This work constrains the emplacement conditions and the source area of RBI, exploring its relations with the CCVC. We conducted fieldwork at the CCVC and performed a systematic sampling for AMS analyses and full magnetic mineralogy characterization. This approach allowed us to determine the flow direction of the RBI PDCs and link the AMS with flow dynamics of these flows. Our data suggest a decrease in transport capacity toward the top of each flow unit, marked by an increase in AMS dispersion and a decrease in the degree 
149 of anisotropy. Directional analysis indicates the Las Mellizas Caldera as the emission center for the RBI.

\section{Geological setting}

Located in the Southern Volcanic Zone (SVZ) of the Andes (Fig. 1), the CCVC

$\left(37^{\circ} 50^{`} \mathrm{~S}, 71^{\circ} 10^{`} \mathrm{~W}\right)$ comprises a singular volcanic center composed of the active stratovolcano Copahue (1.23 Ma - Recent) and the Pliocene Caviahue (also known as Agrio) Caldera (Pesce, 1989; Melnick et al., 2006; Fig. 1). In the SVZ, the magmatic activity occurs as a result of the subduction of the Nazca Plate under the South American Plate, with extensive volcanism of basaltic to andesitic composition (Hildreth and Moorbath, 1988; Stern, 2004). In this context, the CCVC composes one of the most active volcanic centers in the Andean belt, with several eruptive events in the last century (Caselli et al., 2016; Tassi et al., 2016). The particular setting of the CCVC attracted several studies in the recent decades, with a broad range of topics including geomorphology (e.g., Díaz, 2003; Báez et al., 2020a), geochemistry (e.g., Mazzoni and Licitra, 2000; Melnick et al., 2006; Varekamp et al., 2006), geochronology (e.g., Pesce, 1989; Melnicik et al., 2006) structural (e.g., Melnick et al., 2006; Velez et al., 2011; Folguera et al., 2016), geothermal (e.g., Barcelona et al., 2019), and AMS and paleomagnetism (e.g., Ort et al., 2014; Moncinhatto et al., 2019, 2020).

Both Copahue and Caviahue are controlled by a complex structural setting, with significant influence of the oblique subduction of the Nazca Plate on caldera and volcano edifice morphology (Melnick et al., 2006), as well as on vent location and spatial distribution (Stern, 2004; Sielfeld et al., 2017). In addition to this active tectonic setting, several features indicate a strong glacial imprint on CCVC deposits, including U-shaped valleys, striations in lava flows, and moraine deposits (Díaz, 2003; Varekamp et al., 2006; Báez et al., 2020a). The age and intensity of this glaciation are still unclear (Báez et al., 2020a). 
The CCVC is marked by abundant effusive and explosive deposits (Melnick et al., 2006), which extensively cover and partially fill the Caviahue Caldera. Related to Pleistocene evolution, two main pyroclastic units are identified in the region (Mazzoni and Licitra, 2000): the Las Mellizas Volcanic Sequence (LMVS, 2.6 Ma; Linares et al., 1999), which occupies the inner portion of the Caviahue Caldera, and the Riscos Bayos Ignimbrites (RBI, 2.0 - 1.1 Ma; Muñoz and Stern, 1988; Linares et al., 1999), which are prominently located about $15 \mathrm{~km}$ southeast of the Caviahue Caldera but also cover $\sim 100 \mathrm{~km}^{2}$ on the top of the mesa to the east of the caldera (Fig. 1). The LMVS is marked by strongly welded andesitic to dacitic ignimbrites and rheoignimbrites containing abundant lithic fragments (Mazzoni and Licitra, 2000; Melnick et al., 2006; Sommer et al., 2016), interbedded with extensive lava flows (Varekamp et al., 2006).

In contrast, the RBI forms irregular ENE-WSW-trending ridges (Fig. 1) in the Riscos Bayos area and consists of a sequence of predominantly non-welded rhyolitic ignimbrites, with an abundant ash matrix composed of pumice and lithic fragments of volcanic origin (Mazzoni and Licitra, 2000; Melnick et al., 2006; Varekamp et al., 2006). On the mesa to the east of the Caviahue caldera, the ignimbrite, up to $100 \mathrm{~m}$ thick, is incipiently to moderately welded and forms ENE-WSW-trending ridges. Additional mapping of RBI is still necessary to determine the total extent of the deposits (Ort et al., 2014). The available data indicate contrasting ages for RBI, caused either by analytical errors or contamination (Melnick et al., 2006).

Both vent location and nature of the RBI are also poorly constrained. Some studies have associated this ignimbrite sequence with the collapse of the Las Mellizas Caldera (Pesce, 1989; Melnick et al., 2006), a volcano originally located to the west of the Caviahue Caldera where the Copahue Volcano is now located. Others associate RBI with Caviahue Caldera collapse (Mazzoni and Licitra, 2000), while some authors have argued that RBI could not 


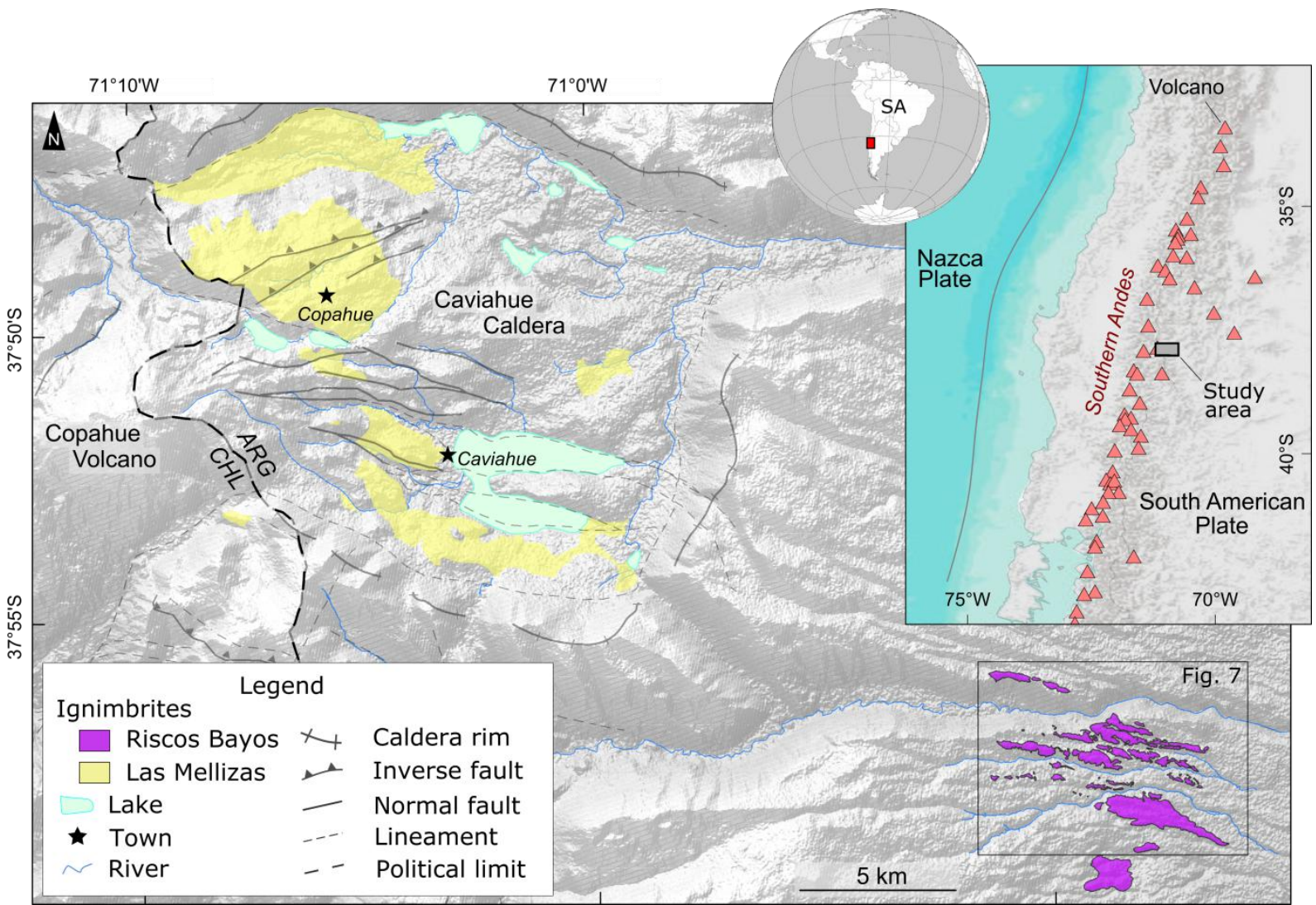

Fig. 1. Shaded relief map of the CCVC with the main ignimbrite deposits, geological features, and structures. ARG - Argentina; CHL - Chile. To the right: inset with the context of the studied area in the globe and in the Southern Andean Belt. SA - South America.

\section{Methods}

\subsection{Fieldwork and paleomagnetic sampling}

RBI outcrops were first identified using Google Earth and available geological maps

209 from the literature (e.g., Melnick et al., 2006). The best accessible RBI exposures occur $15 \mathrm{~km}$

210 SW of the southeastern rim of the Caviahue Caldera, along the Argentinian road number 26.

211 A field evaluation regarding the main structures and primary constituents was performed in

212 every outcrop, including compass measurements. For AMS studies, a total of 144 cores (25.4 $\mathrm{mm}$ in diameter) were obtained from 10 sampling sites using a portable gasoline-powered 
drill. The samples were oriented using a magnetic compass and whenever possible a sun compass for corrections.

\subsection{Laboratory investigations}

\subsubsection{Microscopy}

Thin sections were prepared and analyzed under an optical microscope with transmitted (for silicate fabrics) and reflected light (for Fe-Ti oxide fabrics). Using the software ImageJ (Schindelin et al., 2012), the orientation of the major axis of both silicate and oxide crystals of representative samples were extracted, allowing comparison and validation of the directions obtained using the AMS technique.

CS3 furnace (AGICO). The results were corrected and analyzed using the software Cureval8 
IRM curves and hysteresis loops were determined using small rock chips from each site. Analyses were performed at room temperature using a Princeton Measurements Corporation Micromag vibrating sample magnetometer (VSM) by applying fields up to $1 \mathrm{~T}$. From these analyses, we derived basic parameters, including the saturation magnetization $(M s)$, saturation remanent magnetization $(M r s)$, coercivity $(B c)$, and coercivity of remanence $(B c r)$. In order to model the magnetic components present in our samples, UnMix analyses (Robertson and France, 1994; Kruiver and Passier, 2001; Heslop et al., 2002) were performed using the IRM acquisition curves. Quantification and UnMix fitting were accomplished using 
diamagnetic, paramagnetic and ferromagnetic minerals, depending on their intrinsic anisotropy and spatial distribution within a rock sample (Tarling and Hrouda, 1993). This technique is based on the measurement of the magnetic susceptibility in different directions to resolve the magnetic susceptibility tensor $(K)$, which ultimately represents the shape and orientation of the particles in the sample (represented by the principal axes $K_{1} \geq K_{2} \geq K_{3}$ ), allowing several interpretations related to flow direction and regime in volcanic rocks (Graham, 1954; Cañón-Tapia and Mendoza-Borunda, 2014).

In the laboratory, samples were cut into standard specimens $(25.4 \mathrm{~mm}$ in diameter, 22 $\mathrm{mm}$ in thickness), totaling 144 specimens. AMS analyses were performed on standard specimens from all sites, using an automatic Kappabridge MFK1-A apparatus (AGICO), operated in a low alternating field of $300 \mathrm{~A} / \mathrm{m}$ and a frequency of $976 \mathrm{~Hz}$. Results were processed and interpreted using Anisoft5 (AGICO), and later plotted in a geographic information system (GIS) environment to aid the spatial interpretation. All the stereonets presented are in the bedding coordinate system (bedding being rotated to the horizontal).

All AMS analyses were performed at the USPMag. To reach a more robust directional analysis, we also reprocessed 13 paleomagnetic sites from Ort et al. (2014), who performed an AMS and paleomagnetic analysis in the CCVC with a greater focus on AMS fabrics and their behavior with respect to PDC deposition. In order to better constrain confidence intervals and the principal AMS axes, bootstrap resampling was applied to our samples (Constable and Tauxe, 1990; Tauxe et al., 1991).

(1) 


\section{Results}

\subsection{Field and petrographic aspects}

In the study area the RBI crops out as ENE-WSW-trending ridges marked by distinct tan, white and grey colors (Fig. 2A). The northern section is dominated by tan and grey irregular ridges stretching for up to $\sim 3 \mathrm{~km}$, while the southern section is composed of a white $\sim 4$-km-long continuous ridge. Flow units are tabular, with thickness ranging from a few to 15 m (Fig. 2B). RBI samples are mainly poorly sorted lapilli-tuffs with 20 to $35 \%$ of ash, 65 to $75 \%$ of lapilli, and less than $2 \%$ of block fragments. The lapilli and block fragments are mainly composed pumice (80 - 95\%) fragments, with variable contents of lithic clasts (5 20\%), mainly of andesite and basalt (Fig. 2C, D). Pumice, lithic and crystal are supported by a fine matrix mainly composed of pumice and crystal fragments.

In some sites, the matrix and the clasts present a slight imbrication to the southeast (Fig. 2C). Despite that, massive and graded bedding dominates as the main structures observed in RBI. A normal grading for lithic clasts and an inverse grading for pumice clasts are common, as well as pumice concentration zones. The upper section presents high primary and secondary porosities and is marked by higher pumice contents (Fig. 2D). Pumice fragments can reach up to $20 \mathrm{~cm}$ in diameter. In the basal section, thin horizons with a concentration of lithic clasts are common (Fig. 2E), where lithic fragments can reach up to 30 $\mathrm{cm}$ in diameter. In several locations, a high variation in grain size and distribution occurs, including the sparse presence of blocks and bombs (Fig. 2F). 

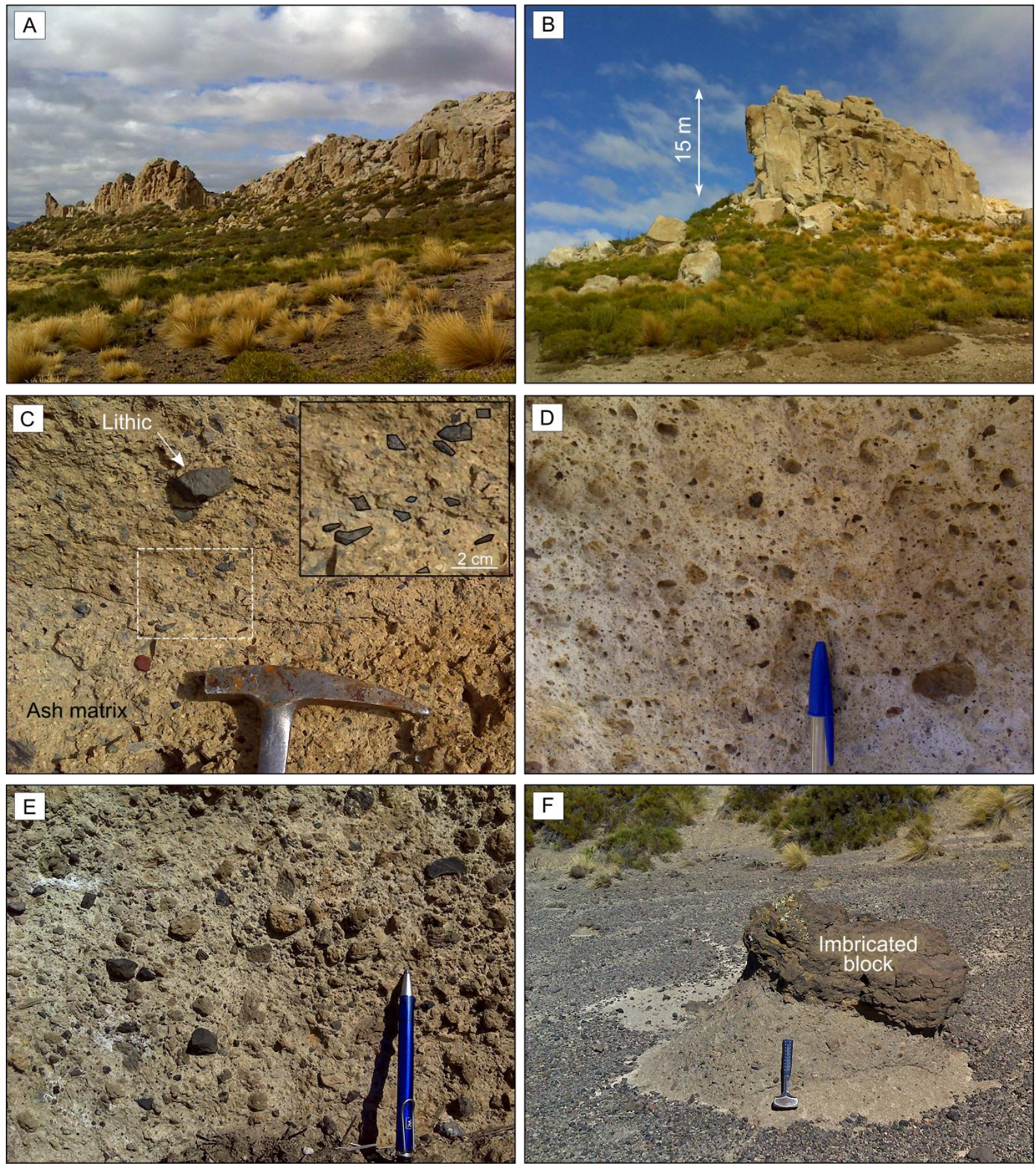

310 Fig. 2. Field and petrographic aspects of RBI. A) ENE-WSW-trending ridges of RBI outcrops; B) outcrop of tan-colored ignimbrite sequence; C) poorly-sorted lapilli-tuff with incipient imbrication (inset); D) upper section pumiceous lapilli-tuff; E) lithic-rich basal section; F) block-sized imbricated fragment.

Under the microscope, RBI samples are marked by pumice, lithic, and crystal

fragments surrounded by fine ash matrix. The ash matrix is predominantly composed of 
317 fragments are typically lapilli, with diameters ranging from 3 to $30 \mathrm{~mm}$ (Fig. 3A-D).

318 Petrographic compositional estimations of RBI main body (Fig. 3C) reveal a predominance of pumice fragments $(66-90 \%)$, followed by crystal (4 - 9\%) and lithic fragments (1 - 3\%). Pumices dominate the lapilli and ash size intervals, while crystals tend to concentrate within the ash fraction (Fig. 3C). The amount of matrix ranges from 15 to $40 \%$. sharp and irregular shapes (Fig. 3A, B, D, E). Volcanic rocks (basaltic to basaltic-andesite in composition) predominate as the main lithic clasts, tipically unaltered, with irregular to slightly rounded shapes (Fig. 3B, D). Pumice fragments are marked by irregular shapes and high porosity values, without signs of welding or viscous/ductile deformation (Fig. 3A porosity in blue, D, E).

Reflected light microscopy reveals the presence of a small, sparse, distribution of FeTi oxides in RBI samples (Fig. 3F-G). These crystals commonly occur as primary crystals, adjacent to the silicate fabric (Fig. 3F), or as crystal fragments disseminated in the ash matrix (Fig. 3G). Fe-Ti oxides in the RBI commonly present diameters $<200 \mu \mathrm{m}$ and are marked by small differences between their major and minor axis, defining a shape anisotropy. Using the software ImageJ (Schindelin et al., 2012), we measured the orientation of the major axis of both silicate and Fe-Ti oxide particles. The results indicate that major axes of both silicates and oxides present similar, almost parallel orientation (rose diagrams in Fig. 3).

Fig. 3. Petrographic aspects of RBI. A) lapilli-tuff rich in crystals (transmitted light); B) lapilli-tuff rich in pumice and lithic fragments (transmitted light); C) compositional estimates and size distribution of pumice, crystal, lithic and matrix of RBI main body. D) lapilli-tuff showing volcanic lithic, pumice, and crystal fragments (transmitted light); E) lapilli-tuff rich in non-welded pumice fragment and ash matrix (transmitted light); F) detail of plagioclase crystal and several Fe-Ti oxides (reflected light); G) detail of ash matrix, pumice fragment, 

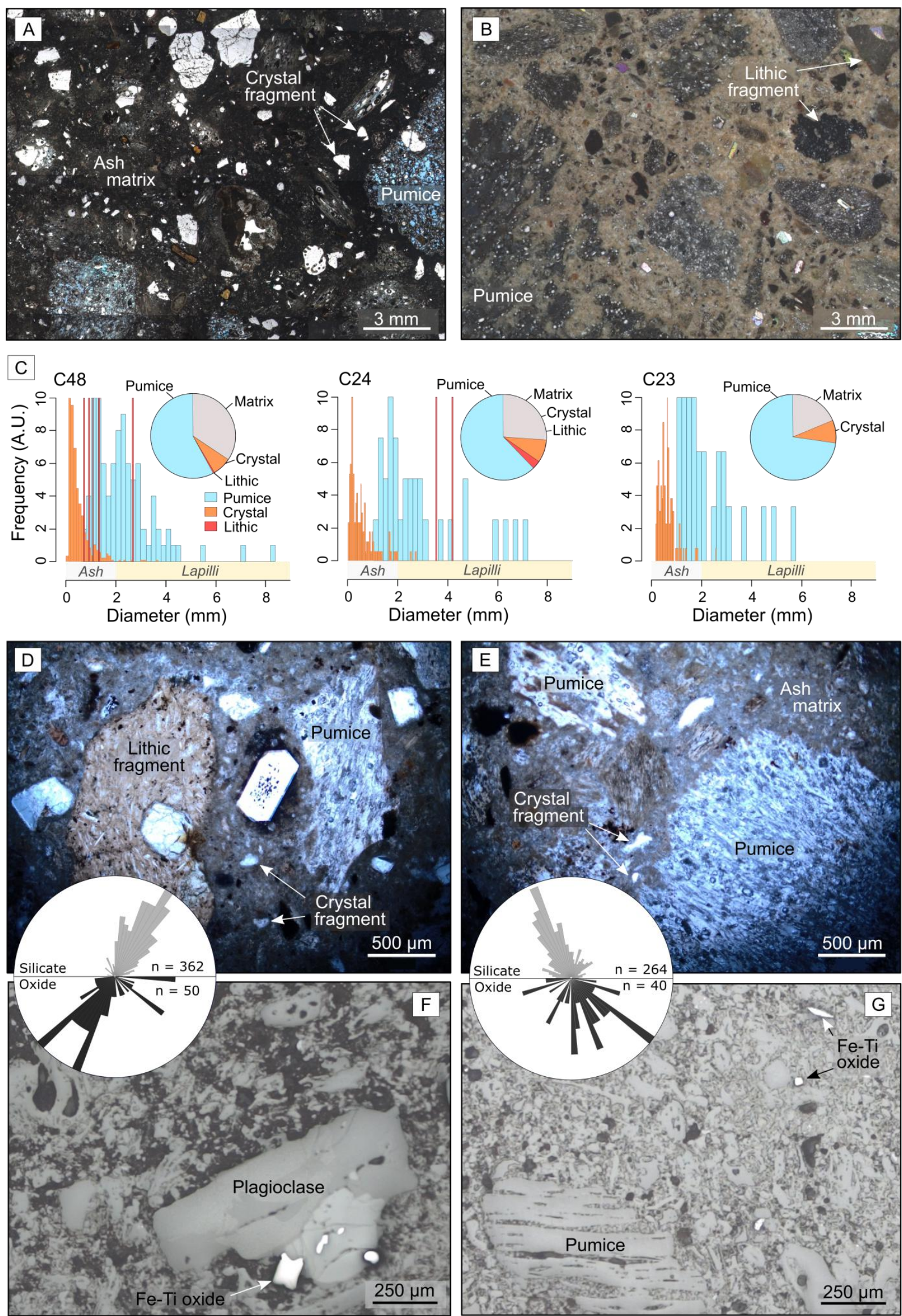


\subsection{Rock magnetism}

Measurements of $\chi$-T curves were carried out in one sample from each site (Table 1) to assist the determination of the magnetic phases, their structure, and alteration history (e.g., Tarling and Hrouda, 1993; Hrouda, 2003). RBI samples present a variety of thermomagnetic curves (Fig. 4A-C), with two main sets of transition temperatures (T). All samples are marked by a high transition temperature $\left(\mathrm{T}_{1}\right)$, ranging from 472 to $580{ }^{\circ} \mathrm{C}$ (Fig. $\left.4 \mathrm{~A}, \mathrm{~B}, \mathrm{C}\right)$. In addition to the $T_{1}$, some samples present a secondary low transition temperature $\left(T_{2}\right)$, ranging from 279 to $410^{\circ} \mathrm{C}$ (Fig. 4B, C). When compared, heating and cooling cycles display minor differences (Fig. 4A, B, C), with small values of the $\mathrm{A}_{40}$ and $\mathrm{A}_{\mathrm{MAX}}$ indices (Hrouda, 2003), suggesting that the susceptibility is mostly reversible and new magnetic phases were not created during the experiment.

Hysteresis loops commonly display a narrow hysteresis, with coercivities $<24 \mathrm{mT}$ (Table 1) and low slopes, suggesting small contents of paramagnetic minerals (Fig. 4D). IRM acquisition curves show that all samples reach saturation with fields ranging from 200 to 400 mT (Fig. 4E; Table 1), which indicates the dominance of low-coercivity magnetic minerals, such as magnetite, maghemite, and greigite, which usually present Ms <300 mT (Dunlop and Özdemir, 1997). However, several samples (Fig. 4E) are not completely saturated at $300 \mathrm{mT}$, which indicates a small concentration of high-coercivity minerals such as hematite and goethite. Hysteresis data, including the ratio of saturation remanence to saturation magnetization $\left(\mathrm{M}_{\mathrm{rs}} / \mathrm{M}_{\mathrm{s}}\right)$ and the coercivity of remanence to coercive force $\left(\mathrm{H}_{\mathrm{cr}} / \mathrm{H}_{\mathrm{c}}\right)$, can be used in the Day plot, a diagram that can help discriminate between single domain (SD), pseudo-single domain (PSD) and multidomain (MD) particles (Day et al., 1977). This differentiation is important because it can have effects on the behavior of the magnetic particles (e.g., Moncinhatto et al., 2020). The RBI samples (Table 1) lie within the pseudoPSD and MD of the Day plot (Fig. 4F, Day et al., 1977). 

observed in RBI samples (Fig. 4G, H, I). Overall, samples are characterized by either a single component or two components (Table 1$)$. Component $1\left(\mathrm{~B}_{1}\right)$ is observed in all samples and provides the strongest contribution to net magnetization (81,2 to $100 \%$ ), with average field ranges from 37.3 to $73.41 \mathrm{mT}$ (Fig. $4 \mathrm{G}, \mathrm{H}$, I; Table 1). A second component $\left(\mathrm{B}_{2}\right)$ is also observed in some samples, with fields ranging from 149.8 to $352.4 \mathrm{mT}$ and contributions of less than $18.7 \%$ to the net magnetization (Fig. $4 \mathrm{H}$; Table 1 ). A third component $\left(\mathrm{B}_{3}\right)$ was detected in only one sample (Fig. 4I; Table 1 - sample C29). $\mathrm{B}_{3}$ displays the lowest coercivity among our samples $(9.3 \mathrm{mT})$, with a contribution to the net magnetization of $15.9 \%$ on sample C29.

FORC diagrams typically display two components (Fig. 4J, K, L), where the first is marked by a spread along the field distribution $(\mathrm{Bu})$ axis and low coercivity $(\mathrm{Bc})$ values and the second is marked by $\mathrm{Bu}$ values centered around zero and a spread along the $\mathrm{Bc}$ axis. The first behavior of FORC distribution is compatible with MD behavior, while the second indicates the presence of samples with vortex domain structure (Roberts et al., 2000, 2017, 2018). Please check supplementary items 1,2, and 3 for a full report on the magnetic experiments. 
Manuscript accepted to Journal of Volcanology and Geothermal Research

Please cite as https://doi.org/10.1016/j.jvolgeores.2021.107283

Table 1

Summary of magnetic mineralogy in RBI samples.

\begin{tabular}{|c|c|c|c|c|c|c|c|c|c|c|}
\hline \multirow[b]{2}{*}{ Unit } & \multirow[b]{2}{*}{ Site } & \multicolumn{6}{|c|}{ Hysteresis and IRM results } & \multirow{2}{*}{$\begin{array}{c}\chi \text {-T curves } \\
\text { Transitions }\left({ }^{\circ} \mathrm{C}\right)\end{array}$} & \multirow{2}{*}{$\begin{array}{l}\text { UnMix processing } \\
\text { Components (mT) }\end{array}$} & \multirow{2}{*}{$\begin{array}{l}\text { FORC } \\
\text { behavior }\end{array}$} \\
\hline & & $\begin{array}{c}\mathrm{M}_{\mathrm{s}} \\
(\mathrm{mAm} / \mathrm{Kg})\end{array}$ & $\begin{array}{c}\mathrm{M}_{\mathrm{rs}} \\
\left(\mathrm{mAm}{ }^{2} / \mathrm{Kg}\right)\end{array}$ & $\begin{array}{c}\mathrm{H}_{\mathrm{c}} \\
(\mathrm{mT})\end{array}$ & $\begin{array}{l}\mathrm{H}_{\mathrm{cr}} \\
(\mathrm{mT})\end{array}$ & $\mathrm{H}_{\mathrm{cr}} / \mathrm{H}_{\mathrm{c}}$ & $\mathrm{M}_{\mathrm{rS}} / \mathrm{M}_{\mathrm{s}}$ & & & \\
\hline RB1 & COP23 & 566.9 & 158.0 & 23.8 & 60.0 & 2.52 & 0.28 & 603 & $62.2\left(\mathrm{~B}_{1}\right), 352.4\left(\mathrm{~B}_{2}\right)$ & SV \\
\hline $\mathrm{RB} 2$ & $\mathrm{COP} 24$ & 322.2 & 45.1 & 10.9 & 40.4 & 3.71 & 0.14 & 472 & $42.7\left(\mathrm{~B}_{1}\right), 149.8\left(\mathrm{~B}_{2}\right)$ & MD \\
\hline RB3 & $\mathrm{COP} 25$ & 824.5 & 126.8 & 20.0 & 54.3 & 2.72 & 0.15 & 580,410 & $70.1\left(\mathrm{~B}_{1}\right)$ & $\mathrm{MD}+\mathrm{SV}$ \\
\hline RB1 & COP26 & 240.5 & 38.6 & 11.8 & 37.0 & 3.13 & 0.16 & 499,279 & $37.3\left(\mathrm{~B}_{1}\right), 207.2\left(\mathrm{~B}_{2}\right)$ & $\mathrm{MD}+\mathrm{SV}$ \\
\hline $\mathrm{RB} 2$ & COP27 & 1034.1 & 144.3 & 15.4 & 35.8 & 2.33 & 0.14 & 567 & $46.1\left(\mathrm{~B}_{1}\right)$ & MD \\
\hline RB2 & COP29 & 423.9 & 32.66 & 6.2 & 30.5 & 4.87 & 0.08 & 535 & $50.2\left(\mathrm{~B}_{1}\right), 9.63\left(\mathrm{~B}_{3}\right)$ & MD \\
\hline RB2 & COP30 & 420.9 & 86.73 & 17.6 & 37.3 & 2.12 & 0.21 & 537 & $50.5\left(\mathrm{~B}_{1}\right)$ & MD \\
\hline RB2 & COP31 & 411.45 & 43.58 & 8.4 & 36.9 & 4.38 & 0.11 & 573,299 & $45.3\left(\mathrm{~B}_{1}\right)$ & MD \\
\hline RB3 & COP48 & 395.4 & 84.2 & 22.8 & 58.3 & 2.55 & 0.21 & 647,579 & $73.4\left(\mathrm{~B}_{1}\right)$ & - \\
\hline RB3 & COP49 & 862.4 & 70.4 & 9.9 & 40.3 & 4.07 & 0.08 & $646,577,484$ & $55.6\left(\mathrm{~B}_{1}\right)$ & - \\
\hline
\end{tabular}

Symbols: FORC states: MD = multi-domain; SV = single-vortex (Roberts et al., 2000, 2017, 2018). 

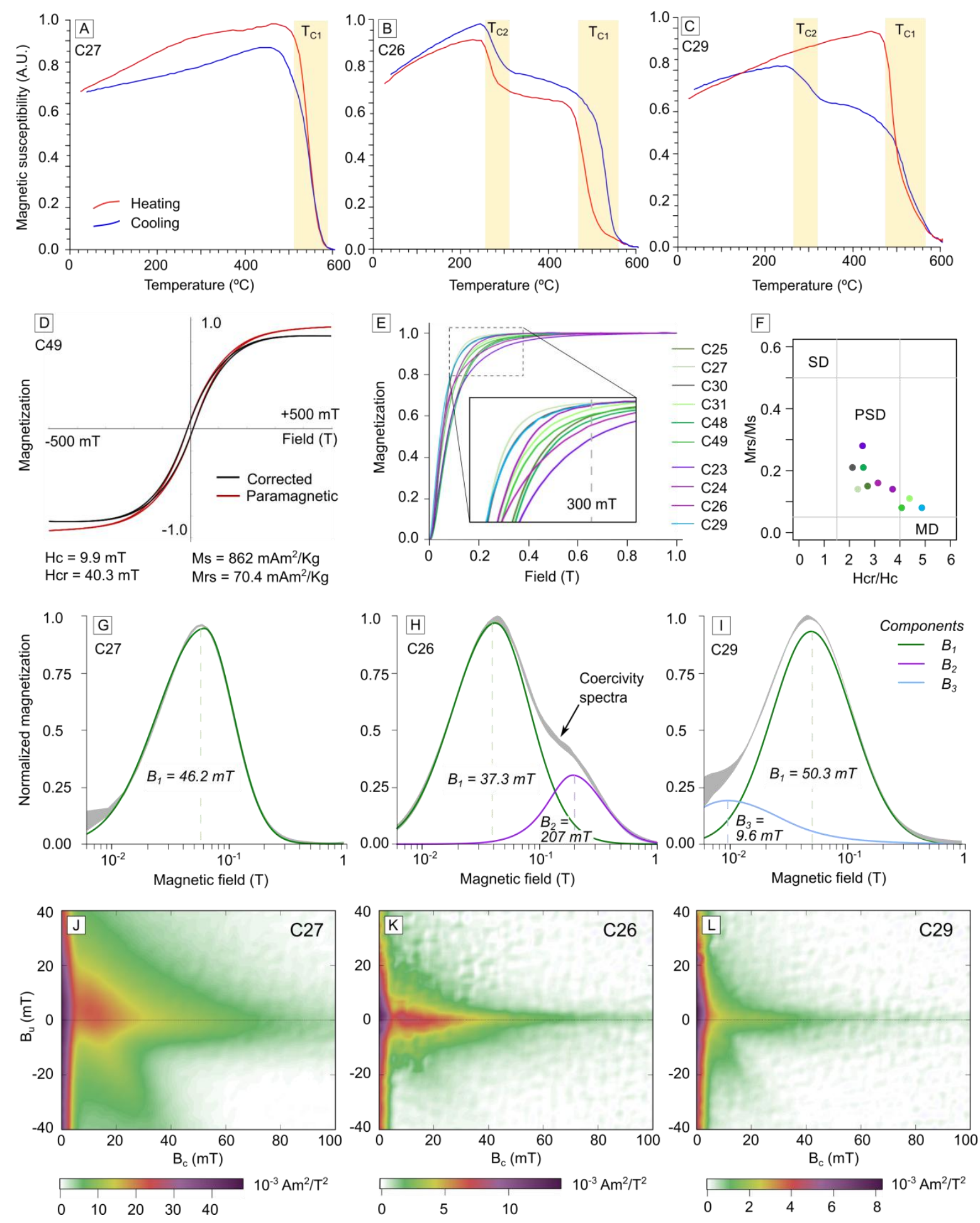

390 Fig. 4. Summary of magnetic experiments: A-C) $\chi$-T curves; D) representative hysteresis loop; E) IRM

391 curves from all sites; F) Day plot (Day et al., 1977), site colors are the same as E; G- I) representative coercivity spectra and UnMix fitting; J-L) representative FORC diagrams. A.U. = Arbitrary Units. 
Manuscript accepted to Journal of Volcanology and Geothermal Research

Please cite as https://doi.org/10.1016/j.jvolgeores.2021.107283

Table 2

AMS results for the studied sites.

\begin{tabular}{|c|c|c|c|c|c|c|c|c|c|c|c|c|c|}
\hline \multirow[b]{2}{*}{ Site } & \multicolumn{2}{|c|}{ UTM coordinates } & \multicolumn{5}{|c|}{ Scalar results } & \multirow[b]{2}{*}{$\begin{array}{l}\mathrm{K}_{1} \mathrm{D} \\
\text { (error) }\end{array}$} & \multirow[b]{2}{*}{$\begin{array}{c}\mathrm{K}_{1} \mathrm{I} \\
\text { (error) }\end{array}$} & \multirow[b]{2}{*}{$\begin{array}{l}\mathrm{K}_{2} \mathrm{D} \\
\text { (error) }\end{array}$} & \multicolumn{3}{|c|}{ Directional results } \\
\hline & $\mathrm{mE}$ & $\mathrm{mN}$ & $\begin{array}{c}\mathrm{Km} \\
\left(10^{-3} \mathrm{SI}\right)\end{array}$ & $\mathrm{L}$ & $\mathrm{F}$ & $\mathrm{P}^{\prime}$ & $\mathrm{T}$ & & & & $\begin{array}{c}\mathrm{K}_{2} \mathrm{I} \\
\text { (error) }\end{array}$ & $\begin{array}{l}\mathrm{K}_{3} \mathrm{D} \\
\text { (error) }\end{array}$ & $\begin{array}{c}\mathrm{K}_{3} \mathrm{I} \\
\text { (error) }\end{array}$ \\
\hline $\mathrm{C} 23$ & 341846 & 5797060 & 7.00 & 1.003 & 1.010 & 1.014 & 0.462 & $065(25)$ & $02(08)$ & $334(25)$ & $11(07)$ & $164(09)$ & $78(07)$ \\
\hline $\mathrm{C} 24$ & 341846 & 5797060 & 3.52 & 1.005 & 1.004 & 1.010 & -0.127 & $337(27)$ & $63(23)$ & $186(14)$ & $23(25)$ & $091(41)$ & $11(22)$ \\
\hline $\mathrm{C} 25$ & 343248 & 5797194 & 3.25 & 1.010 & 1.019 & 1.031 & 0.328 & $299(20)$ & $19(08)$ & $208(21)$ & $02(11)$ & $112(13)$ & $70(08)$ \\
\hline $\mathrm{C} 26$ & 342200 & 5797020 & 2.46 & 1.004 & 1.005 & 1.010 & 0.085 & $310(57)$ & $44(21)$ & $216(57)$ & $03(31)$ & $123(33)$ & $45(21)$ \\
\hline $\mathrm{C} 27$ & 342191 & 5796983 & 6.50 & 1.005 & 1.006 & 1.012 & 0.125 & $297(42)$ & $28(23)$ & $201(43)$ & $11(24)$ & $092(44)$ & $59(25)$ \\
\hline $\mathrm{C} 29$ & 339110 & 5797170 & 4.16 & 1.009 & 1.011 & 1.020 & 0.118 & $312(09)$ & $27(06)$ & $221(12)$ & $03(07)$ & $124(13)$ & $62(06)$ \\
\hline $\mathrm{C} 30$ & 339107 & 5797178 & 3.41 & 1.003 & 1.004 & 1.007 & 0.188 & $310(14)$ & $17(06)$ & 042 (17) & 07 (13) & $154(16)$ & $71(05)$ \\
\hline C31 & 339174 & 5797067 & 2.97 & 1.010 & 1.008 & 1.018 & -0.047 & 277 (33) & $21(12)$ & 009 (32) & 03 (17) & $106(33)$ & $69(10)$ \\
\hline $\mathrm{C} 48$ & 344246 & 5794139 & 3.86 & 1.012 & 1.020 & 1.033 & 0.254 & $279(12)$ & $21(21)$ & $010(25)$ & $02(10)$ & $106(13)$ & $68(11)$ \\
\hline C49 & 342706 & 5795376 & 3.56 & 1.011 & 1.022 & 1.035 & 0.320 & 318 (17) & $22(10)$ & $050(21)$ & 05 (10) & $152(16)$ & $67(10)$ \\
\hline
\end{tabular}




\subsection{SEM observations}

SEM observations and compositional maps obtained using EDS mapping reveal titanomagnetite crystals with variable amounts of Ti as the main oxides present in RBI samples (Fig. 5). These crystals occur especially as free crystals scattered in the ash matrix (Fig. 5A, B, C), as well as inclusions in pumice fragments (Fig. 5B) and silicate crystals (Fig. 5C, D). Minute ferromagnetic crystals are also present in the crystallographic structure of silicate minerals (Fig. 5D). Lithic fragments containing embedded titanomagnetite crystals are also observed (Fig. 5E, F), suggesting some contribution of non-primary magnetic phases to the observed magnetization and possible nature of the AMS signal.

The observed titanomagnetite grains display a wide variation in grain size, distribution, and shape, with a predominance of irregular crystals with diameters ranging from $\sim 10$ to $200 \mu \mathrm{m}$ (Fig. 5). EDS spectra and compositional mapping reveal a predominance of low-Ti titanomagnetite (Ti contents ranging from 9 to $18 \%$ ), although a second population of high-Ti titanomagnetite ( $\mathrm{Ti}$ contents up to 50\%) is also observed in a few samples (Fig. 5C, sample C23). 

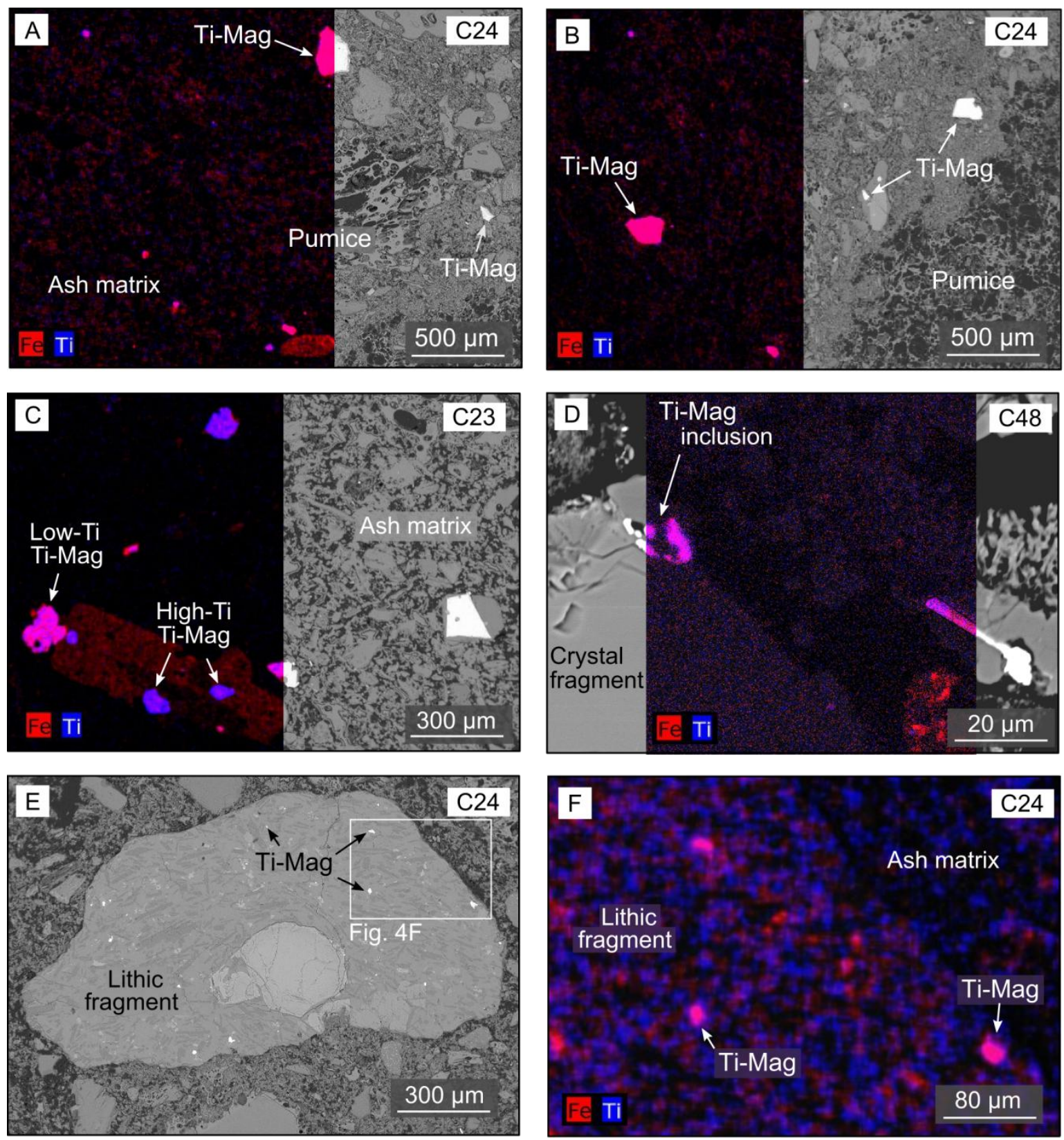

412 Fig. 5. SEM observations of RBI, compositional maps (dark color), and backscattered images (greyscale

413 images). A) titanomagnetite crystals $(\sim 200 \mu \mathrm{m})$ scattered in the ash matrix; B) titanomagnetite crystals $(\sim 100$

$414 \mu \mathrm{m})$ embedded in pumice fragment; $\mathrm{C})$ titanomagnetite crystals with two distinct Ti contents and sizes $(\sim 50$

415 to $150 \mu \mathrm{m}$ ) as inclusion in the silicate fabrics (left) and free crystals (right); D) minute titanomagnetite

416 crystals $(\sim 10 \mu \mathrm{m})$ as inclusions in the crystallographic structure of silicate minerals; E) lithic fragment of

417 andesitic compositions with several embedded Fe-Ti oxides; F) zoom in Fig. 5E, revealing disperse

418 titanomagnetite crystals in the lithic fragment. 


\subsection{AMS and structural data}

A total of 144 specimens were analyzed, in addition to the 145 specimens previously analyzed by Ort et al (2014), representing a total of 23 AMS sites (total of 289 specimens). A summary of both scalar and directional data is presented in Table 2. RBI samples present a low mean magnetic susceptibility $\left(K_{m}\right)$, with most values clustering below $10 \times 10^{-3} \mathrm{SI}$ (Fig. 6A). Notably, some sites from Ort et al. (2014) present high $K_{m}$ values (Fig. 6A, sites $\mathrm{O} 22,25$, and 26), which is associated with the increased welding degree of these sites on the mesa east of Caviahue caldera.

Samples present a low degree of anisotropy (P'), with typical values ranging from 1.003 to 1.05 (Fig. 6B). The higher P' values are observed in samples C48, C49, and O09, notable sites with low Km values and variable T parameters (Fig. 6B, Table 2). The shape parameter $(\mathrm{T})$ of magnetic tensors indicates a predominance of oblate ellipsoids, although some samples may fall within the prolate and triaxial fields (Fig. 6C). Only two sites present prolate tensors (Fig. 6C, C24, and O09). 

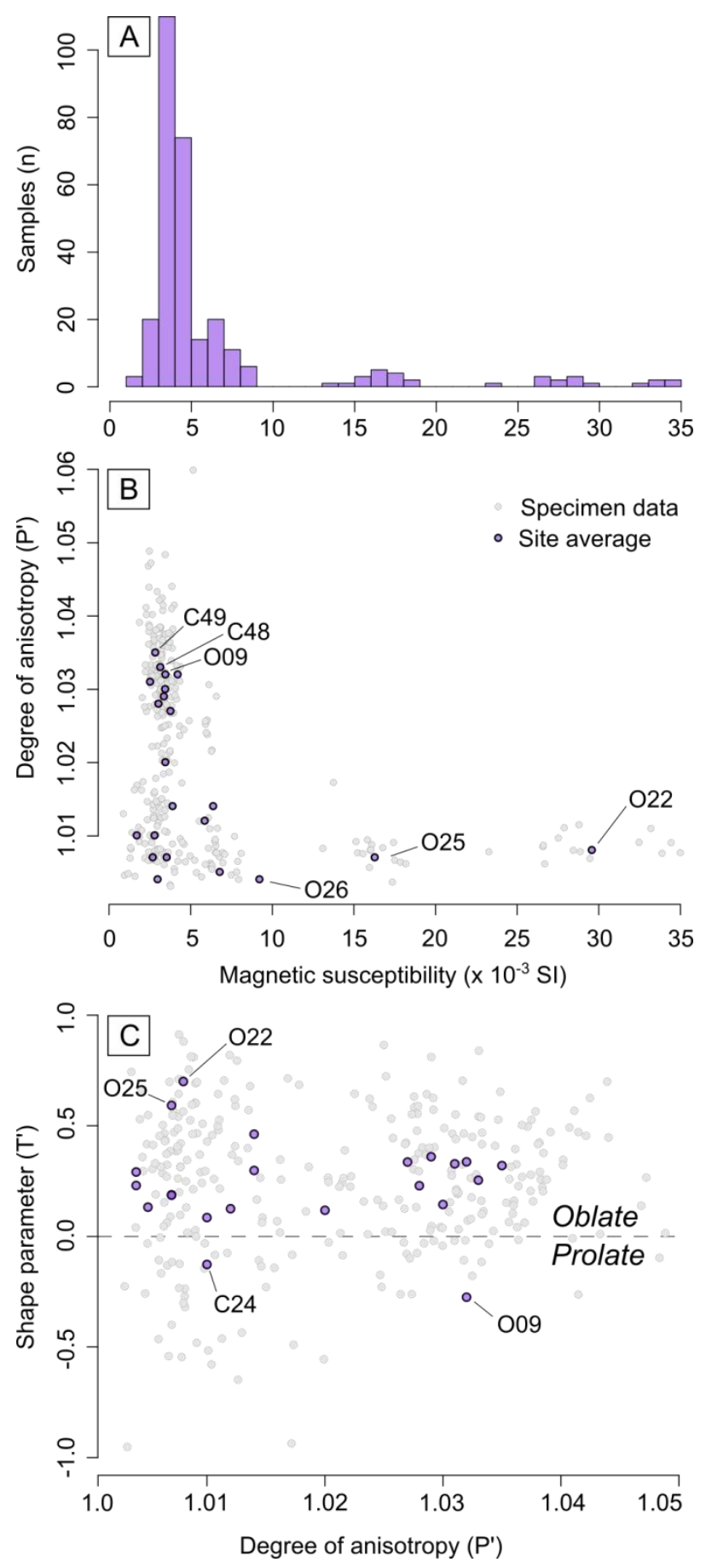

Fig. 6. Summary of AMS scalar results: A) distribution of the bulk magnetic susceptibility; B) degree of

437 anisotropy and the bulk magnetic susceptibility; C) shape parameter and degree of anisotropy.

In order to assist the structural analysis, the AMS directional data were plotted in a

440 detailed map along with representative geological structures (Fig. 7). The magnetic axes

441 within each AMS site are typically well grouped (with the exception of sites C24 and C27 


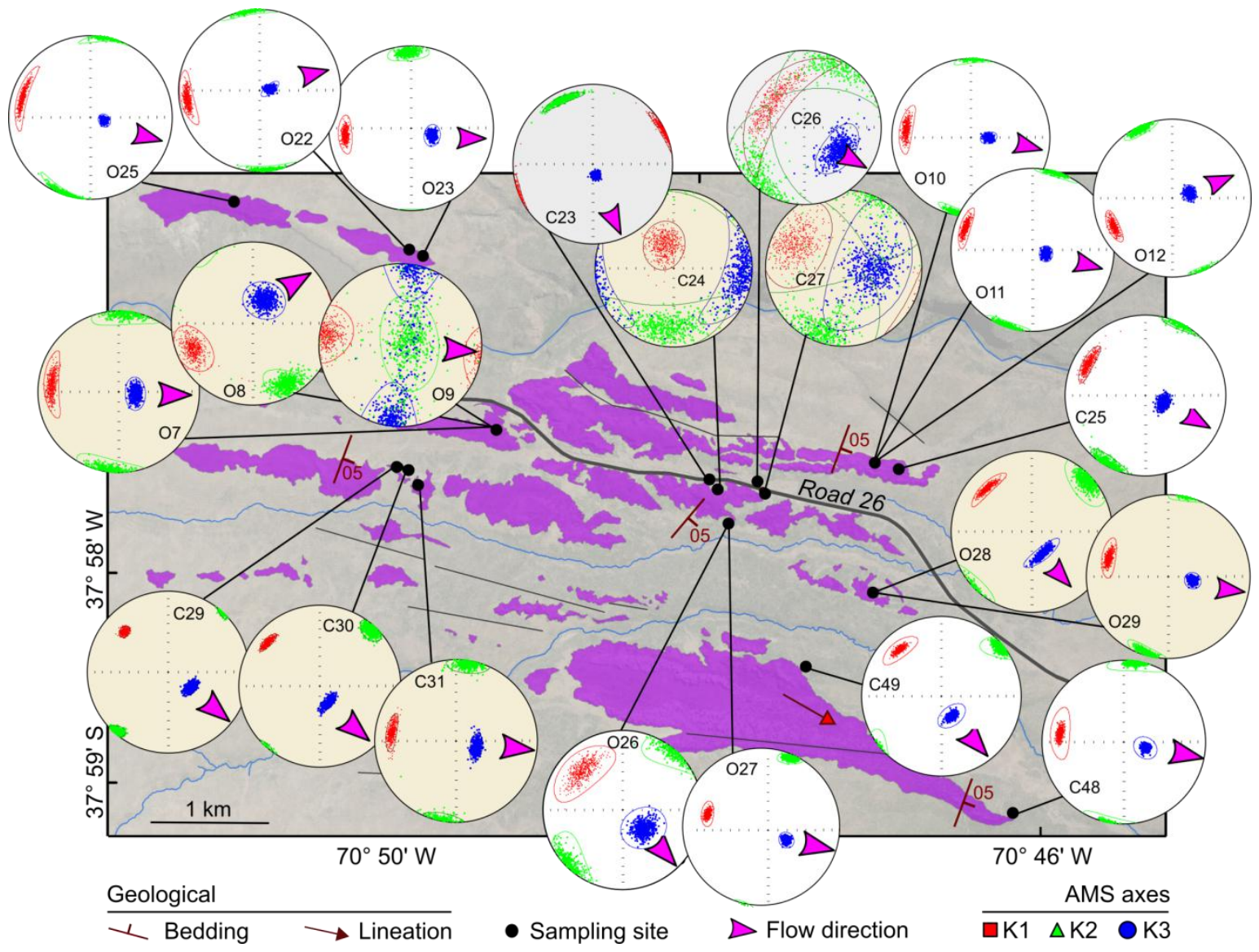

Fig. 7. Geological map of RBI, obtained bootstrapped AMS results, and inferred flow directions.

\section{Discussion}

To identify the source area and volcanological processes associated with the RBI, we integrate fieldwork, AMS, and detailed magnetic mineralogy investigations. In the following sections, we discuss the origin of the magnetic anisotropy, the emplacement dynamics and source area of RBI, and its implications for the CCVC evolution. Finally, we 
compare our results with available AMS data from pyroclastic sequences, addressing some of the questions related to PDC dynamics and emplacement.

\subsection{Origin of the magnetic petrofabrics}

Recent studies have shown that AMS fabric of pyroclastic materials is strongly dependent on microscopic factors, such as composition, mineral magnetic interactions, and domain structure of the Fe-Ti oxides (e.g., Cañón-Tapia and Mendoza-Borunda, 2014;

Moncinhatto et al., 2020). The AMS in pyroclastic deposits results from four main sources (Cañón-Tapia and Mendoza-Borunda, 2014): (1) ferromagnetic phases (mainly Fe-Ti oxides) present as free crystals, (2) ferromagnetic crystals embedded in the ash matrix, pumice, clasts or shards, (3) paramagnetic minerals and (4) ferromagnetic phases as inclusions on the crystallographic structure of ferrosilicate crystals. Our samples present $K_{m}$ values in the range of $10^{-3} \mathrm{SI}$, and according to Tarling and Hrouda (1993) $K_{m}$ values $>10^{-2} \mathrm{SI}$ imply an AMS dominated by the ferromagnetic phases, while $K_{m}<10^{-4} \mathrm{SI}$ suggest an AMS dominated by paramagnetic minerals. The theoretical contribution of paramagnetic minerals to $K_{m}\left(K_{P A R A}\right)$ can be estimated using the geochemical composition of RBI and the equations of Syono (1960) and Rochette et al. (1992):

$$
K_{P A R A}=-14.6+\mathrm{d}\left(25.2 \mathrm{Fe}^{+2}+33.4 \mathrm{Fe}^{+3}+33.8 \mathrm{Mn}^{+2}\right) \text { in } 10^{-6} \mathrm{SI}
$$

where $\mathrm{d}$ is the density of rock (assumed $2.3 \mathrm{~g} / \mathrm{cm}^{3}$ ) and $\mathrm{Fe}^{+2}, \mathrm{Fe}^{+3}$, and $\mathrm{Mn}^{+2}$ are atomic weight percent. For the estimate, we used 16 whole-rock geochemical analyses available in the literature (Mazzoni and Licitra, 2000; Varekamp et al., 2006). On average, $K_{P A R A}$ ranges from $2 \times 10^{-10}$ to $1.4 \times 10^{-9} \mathrm{SI}$, revealing an insignificant paramagnetic contribution to $K_{m}$ and suggesting a main ferromagnetic origin for the AMS in our samples. Petrographic analyses indicate the existence of shape anisotropy in the Fe-Ti oxides. These crystals occur mainly as sparse, inequant crystals in the ash matrix (Fig. 3). 
Directional analysis reveals that both silicate and Fe-Ti oxides present similar orientation (Fig. 3, rose diagrams), indicating an effective orientation of both magnetic and silicate fabrics (Archanjo and Launeau, 2004; Bascou et al., 2005). Considering the sparse occurrence of Fe-Ti oxides and absence of clusters, the effects of distribution anisotropy (i.e., the anisotropy resulting from clusters of magnetic particles; Hargraves et al., 1991) seems to be negligible in our samples. In this context, the resulting magnetic fabrics in RBI are dominated by the shape anisotropy of the ferromagnetic phases (Cañón-Tapia, 2001). Thermomagnetic curves indicate the presence of three magnetic phases: low-Ti titanomagnetite ( $\mathrm{T}_{1}$, Lattard et al., 2006), high-Ti titanomagnetite, and possibly maghemite ( $\mathrm{T}_{2}$, e.g., Dedzo et al., 2011; Lattard et al., 2006). While $\mathrm{T}_{1}$ is observed in all samples, $\mathrm{T}_{2}$ is observed in only half of our dataset. These observations are confirmed by both hysteresis and IRM curves, which point to the predominance of soft magnetic phases with low Hc values grouped in three distinct coercivity components: $\mathrm{B}_{1}(\mathrm{Hc}=37,3$ to $73,41 \mathrm{mT})$, compatible with magnetite, $\mathrm{B}_{2}(\mathrm{Hc}=149,8$ to $352,4 \mathrm{mT})$, compatible with hematite and $\mathrm{B}_{3}$ $(\mathrm{Hc}=9.3 \mathrm{mT})$ compatible with magnetite with larger grain-size when compared to $\mathrm{B}_{1}$ or maghemite (Roberts et al., 1995; Dunlop and Özdemir, 2015).

In all cases, titanomagnetite grains were the dominant phase detected in SEM observations, suggesting a minor contribution of secondary magnetic phases (i.e., maghemite). As a consequence, the variable presence and proportion of coercivity components may be associated with lithological heterogeneities observed in the RBI, as the Fe-Ti oxides embedded in lithic fragments revealed by SEM observations (Fig. 5E, F). Based on the uniform magnetic mineralogy of the studied samples, changes in the AMS fabrics of RBI are linked to flow dynamics. 


\subsection{Flow dynamics and emission area}

The predominance of imbricated oblate fabrics in our samples suggests a

sedimentary-related fabric as the main fabric recorded in the RBI, resulting from the deposition and alignment of inequant ferromagnetic particles in the PDC (Cañón-Tapia and Mendoza-Borunda, 2014). Similar to granular flow in sedimentary systems, the $\mathrm{K}_{1}$ in sedimentary fabrics of PDCs is imbricated and parallel to the flow direction (e.g., Ort, 1993; Cañón-Tapia and Mendoza-Borunda, 2014; Alva-Valdivia et al., 2017). In contrast, the development of shear and post-emplacement fabrics (e.g., slumping, compaction) seems absent in our samples, because the sampled RBI units are predominantly nonwelded (Mazzoni and Licitra, 2000; Melnick et al., 2006) and present emplacement temperature below the minimum welding temperature (Haag et al., 2020).

At a site scale, AMS ellipsoids are generally well defined (Fig. 7, Table 2), with well-grouped axes and consistent ESE $\mathrm{K}_{3}$ imbrication, suggesting nearly stable deposition dynamics (Cañón-Tapia and Mendoza-Borunda, 2014). In contrast, a few sites present large confidence ellipses and dispersion (e.g., sites C24, 26, 27, and O09 in Fig. 7), which may be linked to either poorly defined AMS tensors (low P') or unsteady depositional dynamics (Cañón-Tapia and Mendoza-Borunda, 2014).

When considering a more regional scale (up to a few hundred meters), AMS sites reveal slight variations in the PDC direction. This is highlighted by several groups of proximal sites (e.g., group $\mathrm{C} 30,31$ and group $\mathrm{O} 7,8,9)$ that, despite having sites located just a few meters from each other, present significant directional deviations (up to $33^{\circ}$ in $\mathrm{K}_{1}$ direction in group $\mathrm{O} 7,8,9$ ) in the resulting AMS tensor (Fig. 7). Despite these deviations, a general trend in $\mathrm{K}_{1}$ and $\mathrm{K}_{3}$ is observed across all RBI samples and flow units (Fig. 8). 


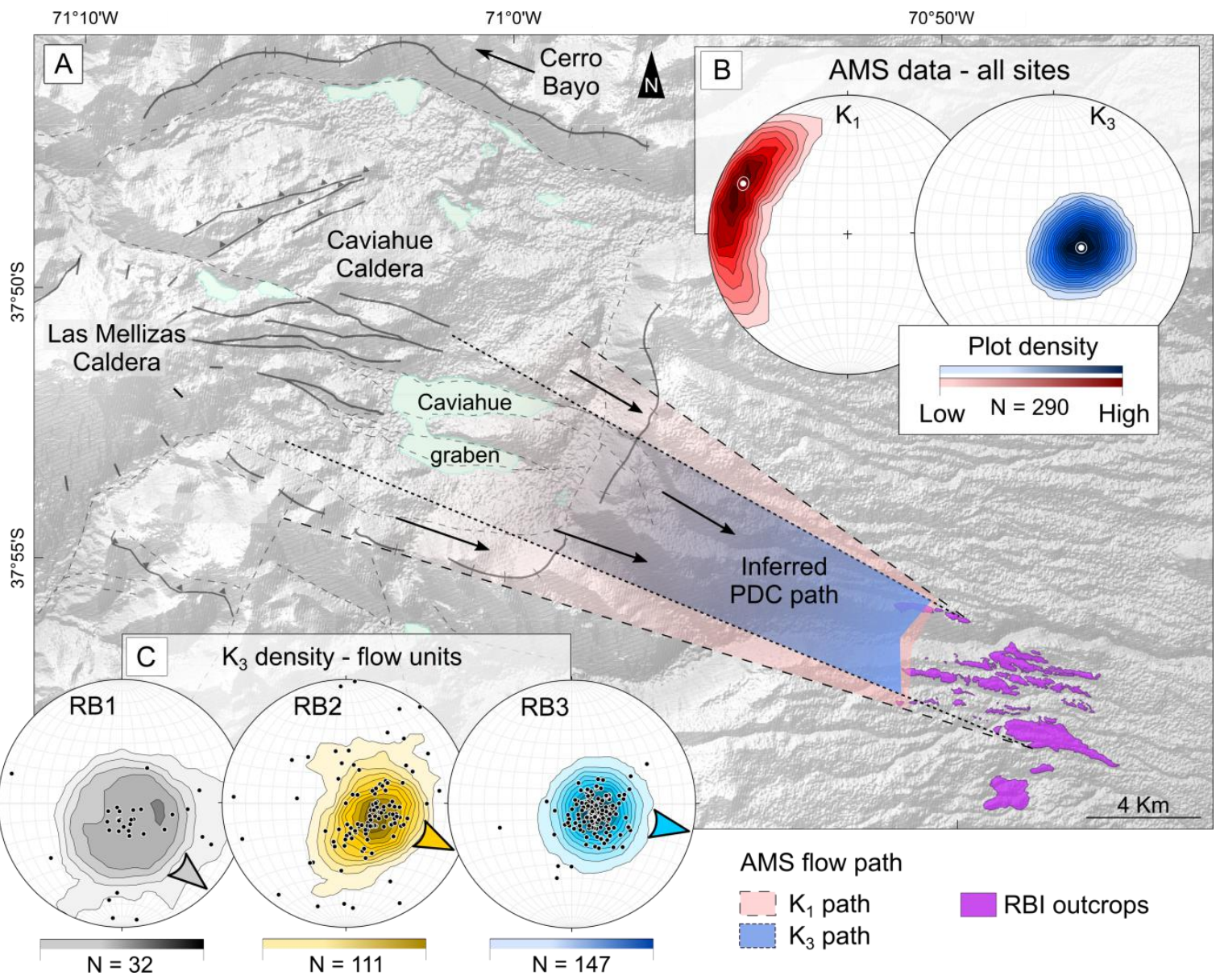

Fig. 8. Reconstruction of the PDC paths and potential source areas. A) Map of the CCVC with possible PDC paths based on both $\mathrm{K}_{3}$ (blue) and $\mathrm{K}_{1}$ (red) AMS measurements; source areas for RBI (in purple) include the Caviahue Caldera, Las Mellizas Caldera (yellow), and Cerro Bayo dome (dark red); B) stereonets with density plots for all $\mathrm{K}_{1}$ and $\mathrm{K}_{3}$ measurements; $\mathrm{C}$ ) stereonets with density plots of $\mathrm{K}_{3}$ measurements for each RBI flow unit.

Directional statistics of the main AMS axes (Fig. 8, upper right stereograms) reveal a mean $K_{1}$ trend of $292^{\circ}\left(\alpha_{95}=5.4^{\circ}\right)$, while $K_{3}$ presents an average trend of $116^{\circ}\left(\alpha_{95}=\right.$ $3.0^{\circ}$ ). AMS directional results can be used to constrain possible PDC paths, considering the $\alpha_{95}$ as limits for the path (Fig. 8, $\alpha_{95}$ of $\mathrm{K}_{1}$ in red and $\alpha_{95}$ of $\mathrm{K}_{3}$ in blue). This approach indicates an emission center located in the southern segment of the Caviahue Caldera (Fig. 8). In this segment, the most prominent emission center is the Las Mellizas Caldera (Pesce, 


\subsection{Volcanological and tectonic implications for CCVC evolution}

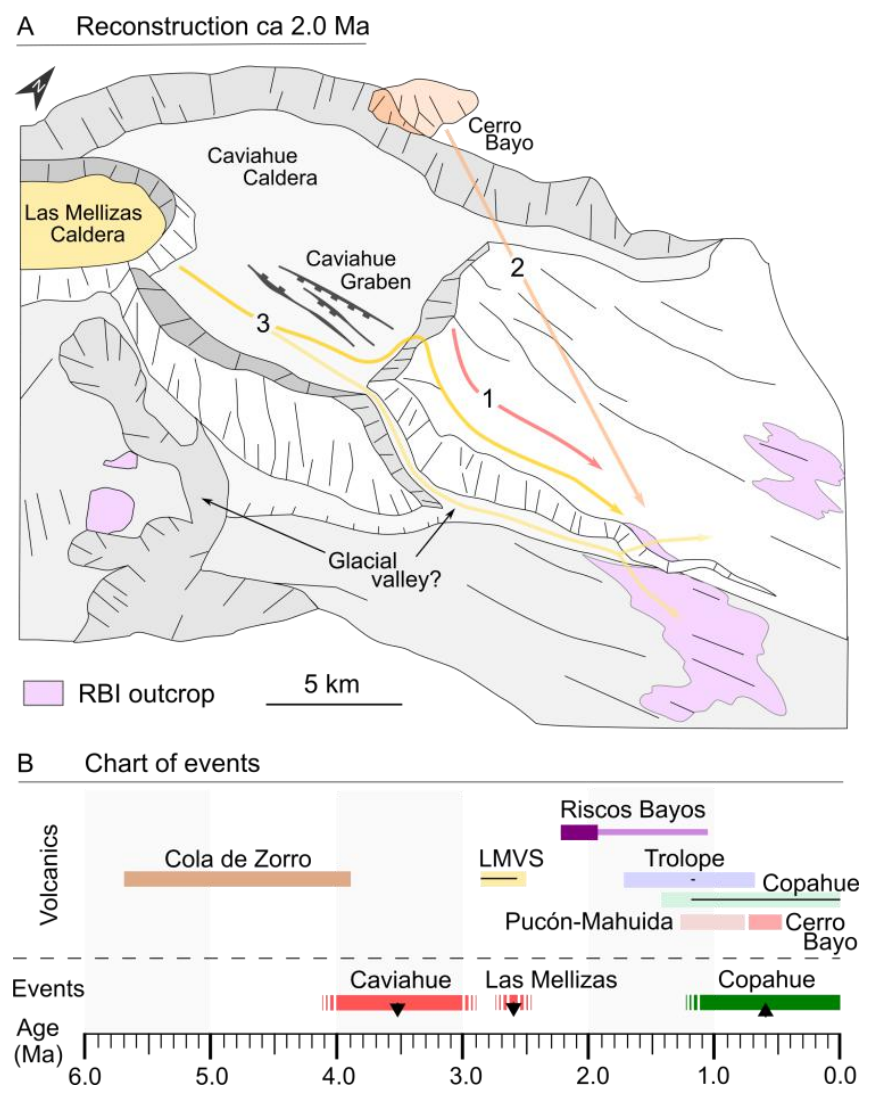

Fig. 9. Proposed source areas for RBI and main events: A) Reconstruction at $\sim 2.0$ Ma with possible PDC paths indicated by arrows: (1) Caviahue Caldera, (2) Cerro Bayo dome, and (3) Las Mellizas Caldera; B) 
Caldera. However, the contrasting ages of the RBI and the onset of the Caviahue depression suggest that these events are most likely unrelated (Fig. 9B; Linares et al., 1999). Furthermore, a recent study by Hernando et al. (2020) in sediments of the Caviahue Graben suggests that Caviahue Caldera was already present prior to the emplacement of the $\sim 2.6$ Ma LMVS.

Additional, small emissions centers have also been mentioned, including subvolcanic bodies such as Cerro Bayo, located to the north of the Caviahue Caldera (Fig. 9A, orange dome). However, contrasting geochemistry (Varekamp et al., 2006) and our AMS data (Fig. 9A, orange arrow number 2) do not support Cerro Bayo as a potential emission center.

Alternatively, another proposed emission center is the Las Mellizas Caldera, originally located to the west of the Caviahue Caldera (Fig. 9A, yellow depression; Pesce, 1989; Melnick et al., 2006). Despite contrasting compositions, samples from LMVS and the $\mathrm{RBI}$ present smooth trends in most $\mathrm{MgO}$ versus major elements plots, as well as compatible REE patterns (Varekamp et al., 2006). In this configuration, Las Mellizas comprises a nested caldera (Pesce, 1989). This setting implies that PDCs originating from Las Mellizas would have to either (i) surpass the $\sim 500$-m-high east wall of the Caviahue Caldera or (ii) follow a canyon to be deposited in the RBI current location (Fig. 9A, upper yellow arrow number 3). 
located in the southeastern Caviahue Caldera rim could offer a path to PDCs originated from the Las Mellizas Volcano collapse (Fig. 9A, lower yellow arrow number 3). However, our AMS data obtained at the end of this glacial valley do not support the lateral spreading of the PDC, and instead, show a rather coherent transport direction to the east-southeast (Fig. 7).

In contrast, field data and numerical simulations have shown that PDCs are capable of overrunning topographic obstacles, even in distal regions (Legros and Kelfoun, 2000; Todesco et al., 2006). The study of Todesco et al. (2006) indicates overrun of $\sim 160 \mathrm{~m}$ height obstacles and suggests that topographic barriers may induce even more collapse of the eruptive column, enhancing PDC propagation. This study also indicates retention of lithic clasts at the topographic barrier followed by the deposition of more pumice-rich ignimbrites downcurrent. Legros and Kelfoun (2000) indicate the scaling of topographic barriers as high as $1500 \mathrm{~m}$ for Taupo pyroclastic flows. In the field, the RBI is marked by the abundance of ash and pumice fragments (which can add up to $>95 \%$ ), with restricted lithic-rich horizons and a massive structure, consistent with internal organization obtained in the simulations of Todesco et al. (2006). The current height of the east Caviahue Caldera wall is $\sim 500 \mathrm{~m}$. This height likely does not represent the original barrier climbed by the PDCs, as the intense glaciations and magmatism in the study region probably increased this collapse since the eruption of the RBI.

In summary, directional AMS and field data support the southern region of the Caviahue Caldera as the emission center for RBI, likely the Las Mellizas Caldera. This tectonic setting of multiple, nested emission centers and calderas is common in the Andes (e.g., Ort, 1993; Chiodi et al., 2019). Despite that, we cannot rule out the possibility of alternative emission areas located both inside and outside the Caviahue Caldera. These virtual emission centers include the Caviahue Graben (Fig. 9A) and volcanic domes 
originally present where the southern canyon is now located. However, geological data do not indicate the presence of conduits, dikes, necks, or subvolcanic bodies in these regions that could have acted as emission centers for the RBI. The AMS data show clearly that the PDCs exited the Caviahue Caldera at the southeast corner and traveled downvalley from there.

\subsection{Implications for PDC dynamics}

In the past decades the AMS has been extensively applied to pyroclastic deposits, mainly as a tool for source area identification (e.g., Palmer and MacDonald, 1999; Hong et al., 2016; Alva-Valdivia et al., 2017). Despite that, few studies have examined how AMS relates to flow dynamics (e.g., Fisher et al., 1993; Baer et al. 1997; Ort et al., 2003, 2014; Giordano et al., 2008; LaBerge et al., 2009). In many explosive deposits, the heterogeneity of magnetic fabrics can lead to distinct interpretations, hampering the understanding of questions related to flow dynamics and emplacement of PDCs (e.g., Moncinhatto et al., 2020; Gambeta et al., 2021). The nearly homogeneous magnetic mineralogy of RBI offers the opportunity to explore these questions.

Several AMS studies show that, for non-welded pyroclastic sequences, the magnetic foliation is commonly imbricated, with both $\mathrm{K}_{1}$ and $\mathrm{K}_{3}$ parallel to flow direction (e.g., Fisher et al., 1993; Ort et al., 2003; Giordano et al., 2008; Cañón-Tapia \& MendozaBorunda, 2014; Ort et al., 2014). This orientation comprises the 'parallel' magnetic fabric observed in most pyroclastic deposits (Agrò et al., 2014). However, many cases display a complex behavior (e.g., LaBerge et al., 2009; Agrò et al., 2014; Alva-Valdivia et al., 2017), expressed through 'oblique', 'transverse', and 'random' fabrics. In these cases, interpreting AMS results and extracting flow direction pose a challenge (e.g., LaBerge et al., 2009; Alva-Valdivia et al., 2017). Deviations from the parallel AMS fabrics in PDCs 
have been attributed to several causes, including flow dynamics (Ort et al., 1999; LaBerge et al., 2009; Agrò et al., 2014; Ort et al., 2014, 2015), and mineralogy (e.g., Rochette et al., 1992; Moncinhatto et al., 2020).

In PDCs, the flow dynamics play a significant role in the distribution and orientation of magnetic particles (Ort et al., 1999, 2014, 2015; Giordano et al., 2008).

Following this reasoning, several studies have associated the orientation of AMS axes with distance from the vent and associated PDC dynamics (e.g., Fisher et al., 1993; Baer et al., 1997; Ort et al., 1999, 2003, 2015; Porreca et al., 2003). In these studies, proximal sites show overlapping, dispersed, or random $\mathrm{K}_{1}$ and $\mathrm{K}_{2}$ axes, while more distal portions tend to result in well-defined axes, with $\mathrm{K}_{1}$ parallel to flow direction (Ort et al., 2014). In addition to that, in proximal regions, the orientation of $\mathrm{K}_{1}$ may also be orthogonal to flow direction, suggesting particle rolling and the development of a transverse AMS fabric (Ort et al., 1999; Agrò et al., 2014). In the RBI, only a single site displays $K_{1}$ perpendicular to flow (C23), configuring a transverse fabric (Ort et al., 1999; Agrò et al., 2014). This site is located in the intermediate section of the RBI and as a consequence, our samples do not replicate a $\mathrm{K}_{1}$ orientation that is dependent on the distance from the vent. In contrast to the distance-dependent model, LaBerge et al. (2009) argue that scattering in AMS fabrics results from the gradual decrease in transport capacity of the PDC with time and changes in particle size. In this model, the upper section of a given flow unit tends to present more scatter $K_{1}$ and $K_{3}$ axes (LaBerge et al., 2009). This pattern in the magnetic fabric of increasing scatter up-section in PDC deposits has been reported only in the welded ignimbrites of the Monte Cimino volcanic center (Italy; LaBerge et al., 2009). Here we document one of the first occurrences of this effect in non-welded PDC deposits. 

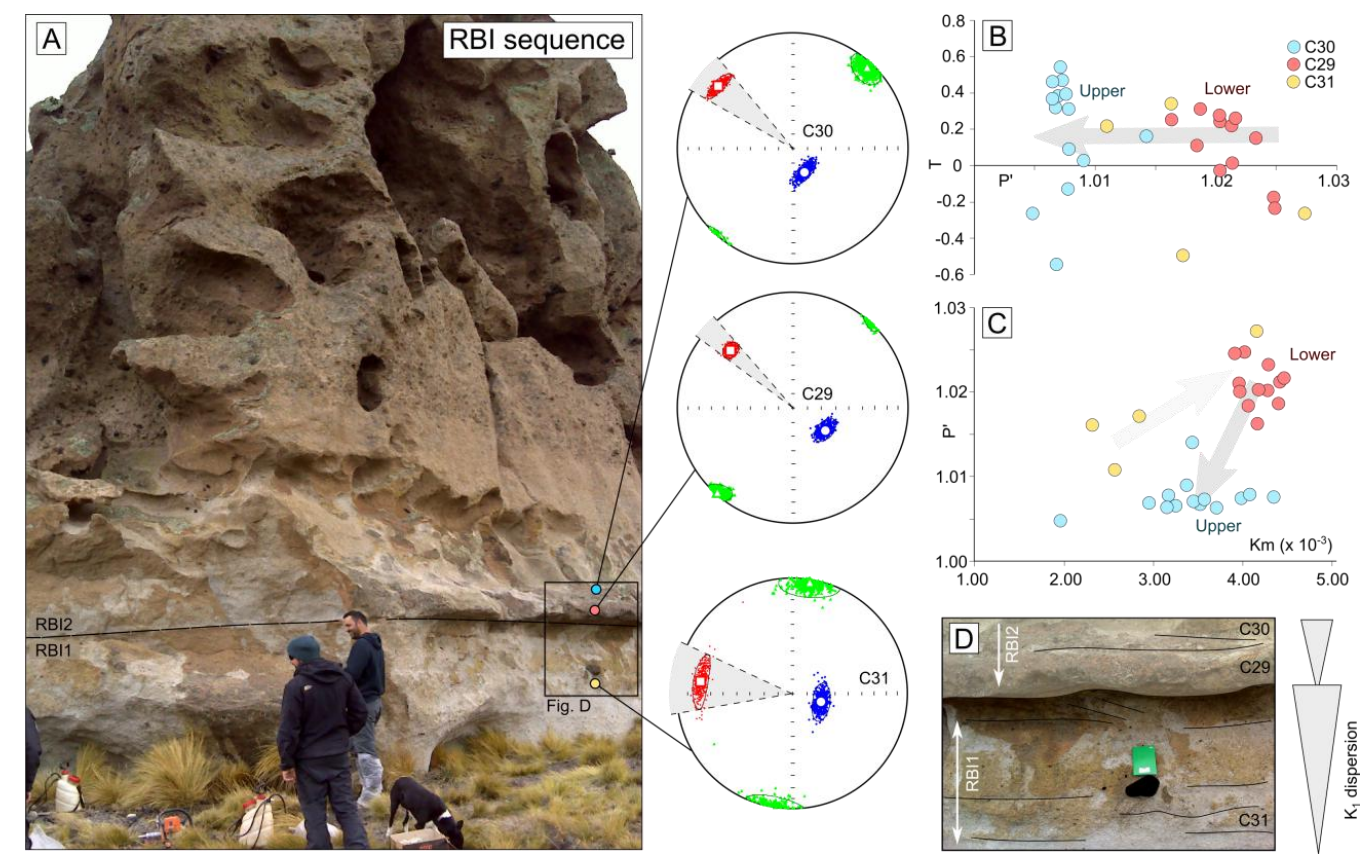

Fig. 10. Evolution of AMS fabrics and dispersion through RBI section: A) RBI flow units with stereonets; B) shape parameter and degree of anisotropy plot; C) degree of anisotropy and magnetic susceptibility plot; D) detail of the pyroclastic section and contact between upper and lower units.

Báez et al. (2020b) explore the pulsating behavior of PDCs at Campo de la Piedra

Pómez ignimbrite (southern Puna), mainly based on extensive field data and facies analysis.

The authors suggest three eruption phases marked by waxing and waning of the PDC. In 
through the use of alternative fabric techniques such as the AMS. The results in RBI samples suggest a stratified behavior of PDCs, which may be present even in massive ignimbrites, such as the studied sequences. The origin of this behavior is associated with pulsatory mechanisms of explosive eruptions (Giordano et al., 2008; Báez et al., 2020b), which explain the distinctive flow units recorded in the RBI.

\section{Conclusions}

We determined the source area and emplacement dynamics of the RBI using fieldwork, AMS, and magnetic mineralogy experiments. The main results for the RBI, the CCVC, and emplacement of PDCs are:

1. The main carriers of the AMS in the RBI are titanomagnetite grains with low Ti content. The titanomagnetite occurs as sparse, primary crystals in the ash matrix.

2. AMS fabrics in RBI are predominantly oblate with $\mathrm{K}_{3}$ imbricated and $\mathrm{K}_{1}$ parallel to flow direction, reflecting dynamics associated with sedimentary PDC fabrics.

3. All three flow units of RBI (RB1, RB2, and RB3) present similar flow directions, with a PDC path consistent with the Las Mellizas Caldera as the emission center.

4. Despite its massive nature, AMS fabrics in the RBI reveal a decrease in transport capacity toward the top of each flow unit.

5. Loss of transport capacity results in an increase of AMS scattering and a decrease of the degree of anisotropy ( $\left.\mathrm{P}^{\prime}\right)$.

\section{Acknowledgments}

This article is part of M.B.H. Master's dissertation at Geosciences Institute at Universidade Federal do Rio Grande do Sul, sponsored by the Conselho Nacional de 
Desenvolvimento Científico e Tecnológico of Brazil [grants number 400724/2014-6, 441766/2014-5, 304036/2018-8, 406925/2018-6, 425728/2018-8, 312737/2020-3] and CAPES AUXPE [2043/2014]. The authors thank all the staff from the Paleomagnetism Laboratory of Universidade de São Paulo (USPMag). We thank Léo A. Hartmann for constructive comments on the manuscript. Finally, we thank Editor Heidy Mader for processing the manuscript, as well as the reviewers for their valuable comments on our study.

\section{References}

Agrò, A., Zanella, E., Le Pennec, J.-L., Temel, A., 2014. Magnetic fabric of ignimbrites: a case study from the Central Anatolian Volcanic Province. Geological Society, London, Special Publications 396, 159-175. https://doi.org/10.1144/sp396.9

Alva-Valdivia, L.M., Agarwal, A., Caballero-Miranda, C., García-Amador, B.I., MoralesBarrera, W., Rodríguez-Elizarraráz, S., Rodríguez-Trejo, A., 2017. Paleomagnetic and AMS studies of the El Castillo ignimbrite, central-east Mexico: Source and rock magnetic nature. Journal of Volcanology and Geothermal Research 336, 140-154.

\section{https://doi.org/10.1016/j.jvolgeores.2017.02.014}

Archanjo, C.J., Launeau, P., 2004. Magma flow inferred from preferred orientations of plagioclase of the Rio Ceará-Mirim dyke swarm (NE Brazil) and its AMS significance. Geological Society, London, Special Publications 238, 285-298.

https://doi.org/10.1144/gsl.sp.2004.238.01.17

Baer, E.M., Fisher, R.V., Fuller, M., Valentine, G., 1997. Turbulent transport and deposition of the Ito pyroclastic flow: Determinations using anisotropy of magnetic susceptibility. J. Geophys. Res. 102, 22565-22586. https://doi.org/10.1029/96jb01277 
Báez, A.D., Báez, W., Caselli, A.T., Martini, M.A., Sommer, C.A., 2020a. The glaciovolcanic evolution of the Copahue volcano, Andean Southern Volcanic Zone, Argentina-Chile. Journal of Volcanology and Geothermal Research 106866. https://doi.org/10.1016/j.jvolgeores.2020.106866

Báez, W., de Silva, S., Chiodi, A., Bustos, E., Giordano, G., Arnosio, M., Suzaño, N., Viramonte, J.G., Norini, G., Groppelli, G., 2020b. Pulsating flow dynamics of sustained, forced pyroclastic density currents: insights from a facies analysis of the Campo de la Piedra Pómez ignimbrite, southern Puna, Argentina. Bull Volcanol 82. https://doi.org/10.1007/s00445-020-01385-5

Barcelona, H., Yagupsky, D., Agusto, M., 2019. The layered model of the Copahue geothermal reservoir, Argentina. Geotherm Energy 7. https://doi.org/10.1186/s40517-019$\underline{0124-9}$

Bascou, J., Camps, P., Marie Dautria, J., 2005. Magnetic versus crystallographic fabrics in a basaltic lava flow. Journal of Volcanology and Geothermal Research 145, 119-135. https://doi.org/10.1016/j.jvolgeores.2005.01.007

Benites, S., Sommer, C.A., Lima, E.F.D., Savian, J.F., Haag, M.B., Moncinhatto, T.R., Trindade, R.I.F.D., 2020. Characterization of volcanic structures associated to the silicic magmatism of the Paraná-Etendeka Province, in the Aparados da Serra region, southern Brazil. An. Acad. Bras. Ciênc. 92. https://doi.org/10.1590/0001-3765202020180981

Cañón-Tapia, E., 2001. Factors affecting the relative importance of shape and distribution anisotropy in rocks: theory and experiments. Tectonophysics 340, 117-131. https://doi.org/10.1016/s0040-1951(01)00150-0 
745 Cañón-Tapia, E., Mendoza-Borunda, R., 2014. Magnetic petrofabric of igneous rocks:

746 Lessons from pyroclastic density current deposits and obsidians. Journal of Volcanology

747 and Geothermal Research 289, 151-169. https://doi.org/10.1016/j.jvolgeores.2014.11.006

748 Cañón-Tapia, E., Walker, G.P.L., Herrero-Bervera, E., 1997. The internal structure of lava

749 flows - insights from AMS measurements II: Hawaiian pahoehoe, toothpaste lava and "a"ā.

750 Journal of Volcanology and Geothermal Research 76, 19-46.

751 https://doi.org/10.1016/s0377-0273(96)00073-x

752 Cas, R.A.F., Wright, H.M.N., Folkes, C.B., Lesti, C., Porreca, M., Giordano, G.,

753 Viramonte, J.G., 2011. The flow dynamics of an extremely large volume pyroclastic flow,

754 the 2.08-Ma Cerro Galán Ignimbrite, NW Argentina, and comparison with other flow types.

755 Bulletin of Volcanology 73, 1583-1609. https://doi.org/10.1007/s00445-011-0564-y

756 Cas, R.A.F., Wright, J.V., 1987. Volcanic Successions Modern and Ancient. Springer

757 Netherlands. https://doi.org/10.1007/978-94-009-3167-1

758 Caselli, A.T., Liccioli, C., Tassi, F., 2016. Risk Assessment and Mitigation at Copahue

759 Volcano, in: Active Volcanoes of the World. Springer Berlin Heidelberg, pp. 239-254.

760 https://doi.org/10.1007/978-3-662-48005-2_10

761 Chiodi, A., Tassi, F., Báez, W., Filipovich, R., Bustos, E., Glok Galli, M., Suzaño, N.,

762 Ahumada, Ma.F., Viramonte, J.G., Giordano, G., Pecoraino, G., Vaselli, O., 2019.

763 Preliminary conceptual model of the Cerro Blanco caldera-hosted geothermal system

764 (Southern Puna, Argentina): Inferences from geochemical investigations. Journal of South

765 American Earth Sciences 94, 102213. https://doi.org/10.1016/j.jsames.2019.102213

766 Constable, C., Tauxe, L., 1990. The bootstrap for magnetic susceptibility tensors. J.

767 Geophys. Res. 95, 8383. https://doi.org/10.1029/jb095ib06p08383 
Day, R., Fuller, M., Schmidt, V.A., 1977. Hysteresis properties of titanomagnetites: Grainsize and compositional dependence. Physics of the Earth and Planetary Interiors 13, 260 267. https://doi.org/10.1016/0031-9201(77)90108-x

Dedzo, M.G., Nédélec, A., Nono, A., Njanko, T., Font, E., Kamgang, P., Njonfang, E., Launeau, P., 2011. Magnetic fabrics of the Miocene ignimbrites from West-Cameroon: Implications for pyroclastic flow source and sedimentation. Journal of Volcanology and Geothermal Research 203, 113-132. https://doi.org/10.1016/j.jvolgeores.2011.04.012 de Silva, S.L., 1989. Altiplano-Puna volcanic complex of the central Andes. Geol 17, 1102. https://doi.org/10.1130/0091-7613(1989)017 $<1102:$ apvcot $>2.3 . c o ; 2$

Díaz, E.F.G. 2003. El englazamiento en la región de Caviahue-Copahue: su reinterpretación. Revista de la Asociación Geológica Argentina, 58(3): 356- 366.

Dunlop, D. J., Özdemir, Ö., 1997. Rock Magnetism. Cambridge University Press. https://doi.org/10.1017/cbo9780511612794

Dunlop, D.J., Özdemir, Ö., 2015. Magnetizations in Rocks and Minerals, in: Treatise on Geophysics. Elsevier, pp. 255-308. https://doi.org/10.1016/b978-0-444-53802-4.00102-0

Ferrari, L., López-Martínez, M., Rosas-Elguera, J., 2002. Ignimbrite flare-up and deformation in the southern Sierra Madre Occidental, western Mexico: Implications for the late subduction history of the Farallon plate. Tectonics 21, 17-1-17-24. https://doi.org/10.1029/2001tc001302

Fisher, R.V., Orsi, G., Ort, M., Heiken, G., 1993. Mobility of a large-volume pyroclastic flow - emplacement of the Campanian ignimbrite, Italy. Journal of Volcanology and Geothermal Research 56, 205-220. https://doi.org/10.1016/0377-0273(93)90017-1 
790 Folguera, A., Rojas Vera, E., Vélez, L., Tobal, J., Orts, D., Agusto, M., Caselli, A., Ramos, 791 V.A., 2016. A Review of the Geology, Structural Controls, and Tectonic Setting of 792 Copahue Volcano, Southern Volcanic Zone, Andes, Argentina, in: Active Volcanoes of the 793 World. Springer Berlin Heidelberg, pp. 3-22. https://doi.org/10.1007/978-3-662-48005$794 \quad \underline{2} 1$

Gambeta, J.H., Savian, J.F., Sommer, C.A., Trindade, R.I.F., 2021. Magnetic anisotropy of an ancient volcanic system: Flow dynamics of post-collisional Ediacaran volcanism in southernmost Brazil. Precambrian Research 359, 106209. https://doi.org/10.1016/j.precamres.2021.106209

Giordano, G., Porreca, M., Musacchio, P., Mattei, M., 2008. The Holocene Secche di Lazzaro phreatomagmatic succession (Stromboli, Italy): evidence of pyroclastic density current origin deduced by facies analysis and AMS flow directions. Bull Volcanol 70, 1221-1236. https://doi.org/10.1007/s00445-008-0198-X

Graham, J. W. 1954. Magnetic susceptibility anisotropy, an unexploited petrofabric element. Geol. Soc. Am. Bull. 65, 1257-1258.

Haag, M., Moncinhatto, T., Sommer, C., Savian, J., Caselli, A., Trindade, R., Hartmann, G., Poletti, W. 2020. Source area and emplacement conditions of Riscos Bayos Ignimbrites, Caviahue-Copahue Volcanic Complex (Argentina). EGU General Assembly 2020. https://doi.org/10.5194/egusphere-egu2020-2704

Haag, M.B., de Freitas, R.B., Sommer, C.A., Savian, J.F., Lima, E.F., Gambeta, J.H., Lyra, D. da S., Trindade, R.I.F. da, 2021. Multi-proxy case study of a Neoproterozoic rhyolite flow in southernmost Brazil: Emplacement mechanisms and implications for ancient felsic 
812 lavas. Journal of South American Earth Sciences 107, 102982.

813 https://doi.org/10.1016/j.jsames.2020.102982

814 Hargraves, R.B., Johnson, D., Chan, C.Y., 1991. Distribution anisotropy: The cause of

815 AMS in igneous rocks? Geophys. Res. Lett. 18, 2193-2196.

816 https://doi.org/10.1029/91g101777

817 Harrison, R.J., Feinberg, J.M., 2008. FORCinel: An improved algorithm for calculating

818 first-order reversal curve distributions using locally weighted regression smoothing.

819 Geochem. Geophys. Geosyst. 9, https://doi.org/10.1029/2008gc001987

820 Hernando, I.R., Bucher, J., del Papa, C.E., Eisermann, J.O., Göllner, P.L., Guzmán, S.R.,

821 Balbis, C., Petrinovic, I.A., 2020. Unraveling the timing of the Caviahue depression,

822 Andean Southern Volcanic Zone: insights from the sedimentary infill. Int J Earth Sci (Geol

823 Rundsch). https://doi.org/10.1007/s00531-020-01936-3

824 Heslop, D., Dekkers, M.J., Kruiver, P.P., Van Oorschot, I.H.M., 2002. Analysis of

825 isothermal remanent magnetization acquisition curves using the expectation-maximization

826 algorithm. Geophysical Journal International 148, 58-64. https://doi.org/10.1046/j.0956-

$827 \quad \underline{540 x .2001 .01558 . x}$

828 Hildreth, W., Moorbath, S., 1988. Crustal contributions to arc magmatism in the Andes of

829 Central Chile. Contr. Mineral. and Petrol. 98, 455-489.

830 https://doi.org/10.1007/bf00372365

831 Hong, H., Yu, Y., Doh, S.-J., Suk, D., Kim, J., 2016. Magnetic Fabrics and Source

832 Implications of Chisulryoung Ignimbrites, South Korea. Front. Earth Sci. 4.

833

https://doi.org/10.3389/feart.2016.00079 
834 Hrouda, F., 1982. Magnetic anisotropy of rocks and its application in geology and

835 geophysics. Geophysical Surveys 5, 37-82. https://doi.org/10.1007/bf01450244

836 Hrouda, F., 2003. Studia Geophysica et Geodaetica 47, 847-861.

837 https://doi.org/10.1023/a:1026398920172

838 Jelinek, V., 1981. Characterization of the magnetic fabric of rocks. Tectonophysics 79, 839 T63-T67. https://doi.org/10.1016/0040-1951(81)90110-4

840 Kruiver, P.P., Passier, H.F., 2001. Coercivity analysis of magnetic phases in sapropel S1 841 related to variations in redox conditions, including an investigation of theSratio. Geochem.

842 Geophys. Geosyst. 2. https://doi.org/10.1029/2001gc000181

843 LaBerge, R.D., Porreca, M., Mattei, M., Giordano, G., Cas, R.A.F., 2009. Meandering flow 844 of a pyroclastic density current documented by the anisotropy of magnetic susceptibility 845 (AMS) in the quartz latite ignimbrite of the Pleistocene Monte Cimino volcanic centre 846 (central Italy). Tectonophysics 466, 64-78. https://doi.org/10.1016/j.tecto.2008.09.009

847 Lattard, D., Engelmann, R., Kontny, A., Sauerzapf, U., 2006. Curie temperatures of 848 synthetic titanomagnetites in the Fe-Ti-O system: Effects of composition, crystal chemistry, 849 and thermomagnetic methods. J. Geophys. Res. 111, https://doi.org/10.1029/2006jb004591

850 Legros, F., Kelfoun, K., 2000. On the ability of pyroclastic flows to scale topographic 851 obstacles. Journal of Volcanology and Geothermal Research 98, 235-241.

852 https://doi.org/10.1016/s0377-0273(99)00184-5 
855 Toconquis Group ignimbrites (Puna plateau, NW Argentina) determined by TRM analyses.

Linares, E., Ostera, H.A. \& Mas, L., 1999. Cronologia potasio-argon del complejo efusivo

Magee, C., Stevenson, C., O’Driscoll, B., Schofield, N., McDermott, K., 2012. An

Maxbauer, D.P., Feinberg, J.M., Fox, D.L., 2016. MAX UnMix: A web application for neógenas con composición intermedia en la zona del lago Caviahue, Neuquén. Revista de la Asociación Geológica Argentina, 55 (3): 188-200.

Melnick, D., Folguera, A., Ramos, V.A., 2006. Structural control on arc volcanism: The

Caviahue-Copahue complex, Central to Patagonian Andes transition $\left(38^{\circ} \mathrm{S}\right)$. Journal of

South American Earth Sciences 22, 66-88. https://doi.org/10.1016/j.jsames.2006.08.008

Moncinhatto, T. R., Oliveira, W.P., Haag, M. B., Hartmann, G.A., Savian, J. F., Poletti, W.,

873 Sommer, C.A., Caselli, A.T., Trindade, R.I.F., 2019. Paleosecular variaton from Northern

874 Patagonia recorded by 0-5 Ma Caviahue-Copahue lava flows. In: Sixth Biennial Meeting of Latinmag, Rancagua. Latinmag Letters. Rancagua,. v. 9. p. 1-7. 
876 Moncinhatto, T.R., Haag, M.B., Hartmann, G.A., Savian, J.F., Poletti, W., Sommer, C.A., 877 Caselli, A.T., Trindade, R.I.F., 2020. Mineralogical control on the magnetic anisotropy of 878 lavas and ignimbrites: a case study in the Caviahue-Copahue field (Argentina).

879 Geophysical Journal International 220, 821-838. https://doi.org/10.1093/gji/ggz483

880

881

882

Morgan, L.A., Doherty, D.J., Leeman, W.P., 1984. Ignimbrites of the Eastern Snake River Plain: Evidence for major caldera-forming eruptions. J. Geophys. Res. 89, 8665. https://doi.org/10.1029/jb089ib10p08665

Muñoz, J.B., and Stern, C.R., 1988, The Quaternary volcanic belt of the southern continental margin of South America: Transverse structural and petrochemical variations across the segment between 38S and 39S: Journal of South American Earth Sciences, v. 1, no. 2, p. 147-161. https://doi.org/10.1016/0895-9811(88)90032-6

Ort, M.H., 1993. Eruptive processes and caldera formation in a nested downsagcollapse caldera: Cerro Panizos, central Andes Mountains. Journal of Volcanology and Geothermal Research 56, 221-252. https://doi.org/10.1016/0377-0273(93)90018-m

Ort, M.H., Rosi, M., Anderson, C.D., 1999. Correlation of deposits and vent locations of the proximal Campanian Ignimbrite deposits, Campi Flegrei, Italy, based on natural remanent magnetization and anisotropy of magnetic susceptibility characteristics. Journal of Volcanology and Geothermal Research 91, 167-178. https://doi.org/10.1016/s0377-

\section{$\underline{0273(99) 00034-7}$}

Ort, M.H., Newkirk, T.T., Vilas, J.F., Vazquez, J.A., 2014. Towards the definition of AMS facies in the deposits of pyroclastic density currents. Geological Society, London, Special Publications 396, 205-226. https://doi.org/10.1144/sp396.8 
Ort, M.H., Orsi, G., Pappalardo, L., Fisher, R.V., 2003. Anisotropy of magnetic susceptibility studies of depositional processes in the Campanian Ignimbrite, Italy. Bulletin of Volcanology 65, 55-72. https://doi.org/10.1007/s00445-002-0241-2

Ort, M.H., Porreca, M., Geissman, J.W., 2015. The use of palaeomagnetism and rock magnetism to understand volcanic processes: introduction. Geological Society, London, Special Publications 396, 1-11. https://doi.org/10.1144/sp396.17

Palmer, H.C., MacDonald, W.D., 1999. Anisotropy of magnetic susceptibility in relation to source vents of ignimbrites: empirical observations. Tectonophysics 307, 207-218. https://doi.org/10.1016/s0040-1951(99)00126-2

Pasqualon, N.G., Savian, J.F., Lima, E.F., Luz, F.R, Moncinhatto, T.R., Trindade, R.I.F, 2020. Emplacement dynamics of alkaline volcanic and subvolcanic rocks in Trindade Island, Brazil. Journal of Volcanology and Geothermal Research 406, 107078.

https://doi.org/10.1016/j.jvolgeores.2020.107078

Pesce, A. 1989. Evolución volcano-tectónica del complejo efusivo Copahue- Caviahue y su modelo geotérmico preliminar. Revista de la Asociación Geológica Argentina, 44: 307327

Platzman, E.S., Sparks, R.S.J., Cooper, F.J., 2020. Fabrics, facies, and flow through a large-volume ignimbrite: Pampa De Oxaya, Chile. Bull Volcanol 82. https://doi.org/10.1007/s00445-019-1345-2

Porreca, M., Mattei, M., Giordano, G., De Rita, D., Funiciello, R., 2003. Magnetic fabric and implications for pyroclastic flow and lahar emplacement, Albano maar, Italy. J. Geophys. Res. 108. https://doi.org/10.1029/2002jb002102 
920 Roberts, A.P., Almeida, T.P., Church, N.S., Harrison, R.J., Heslop, D., Li, Y., Li, J.,

921 Muxworthy, A.R., Williams, W., Zhao, X., 2017. Resolving the Origin of Pseudo-Single

922 Domain Magnetic Behavior. J. Geophys. Res. Solid Earth 122, 9534-9558.

923 https://doi.org/10.1002/2017jb014860

924 Roberts, A.P., Cui, Y., Verosub, K.L., 1995. Wasp-waisted hysteresis loops: Mineral

925 magnetic characteristics and discrimination of components in mixed magnetic systems. J.

926 Geophys. Res. 100, 17909-17924. https://doi.org/10.1029/95jb00672

927 Roberts, A.P., Pike, C.R., Verosub, K.L., 2000. First-order reversal curve diagrams: A new

928 tool for characterizing the magnetic properties of natural samples. J. Geophys. Res. 105,

929 28461-28475. https://doi.org/10.1029/2000jb900326

930 Roberts, A.P., Tauxe, L., Heslop, D., Zhao, X., Jiang, Z., 2018. A Critical Appraisal of the 931 "Day” Diagram. J. Geophys. Res. Solid Earth 123, 2618-2644.

932 https://doi.org/10.1002/2017jb015247

933 Robertson, D.J., France, D.E., 1994. Discrimination of remanence-carrying minerals in 934 mixtures, using isothermal remanent magnetization acquisition curves. Phys. Earth planet. 935 Inter. 82, 223-234.

936 Rochette, P., Jackson, M., Aubourg, C., 1992. Rock magnetism and the interpretation of 937 anisotropy of magnetic susceptibility. Rev. Geophys. 30, 209.

938 https://doi.org/10.1029/92rg00733

939 Schindelin, J., Arganda-Carreras, I., Frise, E., Kaynig, V., Longair, M., Pietzsch, T.,

940 Preibisch, S., Rueden, C., Saalfeld, S., Schmid, B., Tinevez, J.-Y., White, D.J., Hartenstein,

941 V., Eliceiri, K., Tomancak, P., Cardona, A., 2012. Fiji: an open-source platform for

942 biological-image analysis. Nat Methods 9, 676-682. https://doi.org/10.1038/nmeth.2019 
943 Sielfeld, G., Cembrano, J., Lara, L., 2017. Transtension driving volcano-edifice anatomy:

944 Insights from Andean transverse-to-the-orogen tectonic domains. Quaternary International

945 438, 33-49. https://doi.org/10.1016/j.quaint.2016.01.002

946 Sommer, C. A., Haag, M. B., Caselli, A. T. 2016. Determinação numérica de parâmetros

947 reológicos para sistemas vulcânicos de diferentes composições e idades. In: X Simpósio

948 Sul-Brasileiro de Geologia, Curitiba. Boletim de Resumos do X Simpósio Sul-Brasileiro de

949 Geologia. Curitiba: SBG/UFPR, 2017. v. 10.

950 Sparks, R.S.J., 1976. Grain size variations in ignimbrites and implications for the transport

951 of pyroclastic flows. Sedimentology 23, 147-188. https://doi.org/10.1111/j.1365-

$952 \quad \underline{3091.1976 . t b 00045 . x}$

953 Stern, C.R., 2004. Active Andean volcanism: its geologic and tectonic setting. Revista

954 geológica de Chile 31. https://doi.org/10.4067/s0716-02082004000200001

955 Syono, Y., 1960. Magnetic Susceptibility of Some Rock Forming Silicate Minerals Such as

956 Amphiboles, Biotites, Cordierites and Garnets. J. geomagn. geoelec 11, 85-93.

957 https://doi.org/10.5636/jgg.11.85

958 Tarling, D. H., Hrouda, F., 1993. The Magnetic Anisotropy of Rocks. London: Chapman \&

959 Hall, 217p. https://doi.org/10.1002/gj.3350300111

960 Tassi, F., Vaselli, O., Caselli, A.T. (Eds.), 2016. Copahue Volcano, Active Volcanoes of

961 the World. Springer Berlin Heidelberg. https://doi.org/10.1007/978-3-662-48005-2

962 Tauxe, L., Banerjee, S.K., Butler, R.F., Van Der Voo R., 2018. Essentials of

963 Paleomagnetism, 5th Web Edition 
964 Tauxe, L., Kylstra, N., Constable, C., 1991. Bootstrap statistics for paleomagnetic data.

965 Journal of Geophysical Research 96, 11723. https://doi.org/10.1029/91jb00572

966 Todesco, M., Neri, A., Esposti Ongaro, T., Papale, P., Rosi, M., 2006. Pyroclastic flow

967 dynamics and hazard in a caldera setting: Application to Phlegrean Fields (Italy). Geochem.

968 Geophys. Geosyst. 7, n/a-n/a. https://doi.org/10.1029/2006gc001314

969 Varekamp, J.C., deMoor, J.M., Merrill, M.D., Colvin, A.S., Goss, A.R., Vroon, P.Z.,

970 Hilton, D.R., 2006. Geochemistry and isotopic characteristics of the Caviahue-Copahue

971 volcanic complex, Province of Neuquén, Argentina, in: Evolution of an Andean Margin: A

972 Tectonic and Magmatic View from the Andes to the Neuquén Basin ( $35^{\circ}-39^{\circ} \mathrm{S}$ Lat).

973 Geological Society of America. https://doi.org/10.1130/2006.2407(15)

974 Velez, M.L., Euillades, P., Caselli, A., Blanco, M., Díaz, J.M., 2011. Deformation of

975 Copahue volcano: Inversion of InSAR data using a genetic algorithm. Journal of

976 Volcanology and Geothermal Research 202, 117-126.

977 https://doi.org/10.1016/j.jvolgeores.2011.01.012 